\section{ELS ULLS DEL VESCOMTE. MIRADES, MUTACIONS I TRASBALSOS DEL SEPULCRE GÒTIC DE RAMON FOLC DE CARDONA, EL PROHOM VINCULADOR, A POBLET}

\author{
Endreça, o exordi, que diria aquell
}

Emprendre una recerca sobre l'escabrós cas d'una tomba usada per a més $d^{\prime} u n$ mort i d'un mort amb més d'una tomba pot semblar una ocupació morbosa, amb un tètric tràfec de cadàvers, però aquest és un dels riscos quan el tema és l'escultura funerària, tan important com a matèria d'estudi de la història de l'art, medieval o no. Que el nostre difunt, un aristòcrata a cavall del 1300, tingués de primer una tomba gòtica i que, tres segles més tard, se'I volgués honorar renovant el lloc del seu repòs amb un nou sepulcre barroc, és l'excusa, feble si es vol, per a què sigui aquest el treball amb què, tard i malament, vull recordar I'enyorat Joaquim Garriga a la revista del departament on el vaig conèixer. Ell fou el meu primer professor d'història de l'art a la facultat i va pesar decididament en la meva decisió de dedicar-me a aquesta bella disciplina. Que el difunt medieval homenatjat amb una tomba barroca sigui, doncs, el pretext per homenatjar amb l'estudi de les peripècies d'una tomba gòtica al savi expert en art barroc, -sense que m’oblidi, és clar, del Renaixement que tant el va ocupar, a les classes i a la recerca. Un expert, així, en art modern, -un modernista, com els anomenem els medievalistes- encara que, de fet, fos un mestre antic, o a l'antiga, que s'hauria esgarrifat si hagués hagut de fer, com nosaltres en l'any de la pandèmia, classes on line i que es complaïa àmpliament i magistralment en el vell art de la conversa. No em perdonaré mai totes les que no hi vaig tenir i envejaré tota la vida amb fosca gelosia els que $\mathrm{n}$ 'hi van tenir moltes més que jo, entre ells en Joan Bosch que -encara que implicat en aquest afer en tant que I'autor d'un ja remot estudi sobre els Grau, escultors del referit túmul barroc-, si ara surt invocat aquí ho és en raó a la nostra encara més remota amistat, tan Iligada al record d'en Quim. Que I'orientació $\mathrm{d}^{\prime}$ aquest meu treball ${ }^{1}$ tingui una marcada dimensió patrimonial pot ser una coartada suplementària per a aquesta sentida trobada virtual.
MATÈRIA, NÚM. 18-19, 2021 ISSN 1579-2641, p. 27-61

Recepció: 4-11-2020

Acceptació: 14-1-2021

Aquest estudi s'enquadra dins el projecte de recerca HAR2017-85910-P de la Universitat de Barcelona, finançat pel Ministeri d'Economia i Competitivitat. Faig constar des $d^{\prime}$ aquí que $m^{\prime}$ importa un rave el fet que publicar-lo a la revista del mateix departament on imparteixo classes em sigui penalitzat en la valoració del meu currículum i en la seva puntuació numèrica al GRAD. 
2 No conec cap estudi que abordi l'origen i el sentit precís d'aquest curiós sobrenom del vescomte i tampoc no m'entretindré a discutir el numeral que li pertoca, que la bibliografia moderna, amb la GEC al capdavant, anomena Ramon Folc VI (ja ho feia J. Serra Vilaró, Història de Cardona, vol. I: Els senyors de Cardona, Tarragona, 1966, p. 230-267), malgrat que les fonts antigues el numeren com a $X$, segurament a partir del cronista siscentista Bernardo Joseph Llobet Declaración del árbol la genealogia y descendència de los antiquíssimos, nobilíssimos y excelentíssimos vizcondes, condes y duques de Cardona en el Principado de Cataluña, Barcelona, 1665; ho fan la divulgada obra del pare Jaume Finestres i els seus lectors vuitcentistes (vid. infra), mentre que per a altres autors del segle $x x$ és viI (José BALLARÓ Y CASALs i Juan SERRA Y VILARó, Historia de Cardona, Barcelona, 1906, p. 78), V (S. SOBREQUÉs VIDAL, Els barons de Catalunya, Barcelona, 1961, p. 113, Ferran SoldeviLA, Les quatre grans cròniques, revisió del text, pròleg i notes per..., Barcelona, 1971, p. 1243) o IV (Martí de Riquer, L'arnès del cavaller. Armes $i$ armadures catalanes medievals, Barcelona, 1968, p. 71).

3 Agustí Duran i Sanpere, Els retaules de pedra, vol. I, Barcelona 1932, p. 26, on es parla també de les semblances amb les mènsules del rerecor de la catedral de Tarragona. No pretenc fer ara ni la revisió d'un corpus d'escultures formalment interrelacionades ni un estat de la qüestió exhaustiu sobre el tema, però val la pena assenyalar, com a fites historiogràfiques

\section{Un nou fragment i un lloc nou per a una tomba pobletana}

És prou sabuda la devastació que van patir el monestir de Poblet i els seus conjunts funeraris a partir de l'assalt i saqueig vandàlic del 1835 i al Ilarg de la resta del segle XIx. I ho és també la lamentable reconstrucció dels panteons reials feta per Frederic Marès a la postguerra, ja a la segona meitat del segle $x x$ y sota un nacionalcatolicisme oposat i simètric a l'anticlericalisme del XIX, ambdós conjurats en el desmembrament i la pèrdua material i significativa dels importants grups escultòrics executats entre els segles XIV i xVII. Ara bé, ni totes les destruccions ni totes les reconstruccions van succeir exclusivament en els dos moments esmentats, sinó que la llarga història de Poblet permet resseguir altres episodis particulars de mutacions successives de les obres.

Un cas ben paradigmàtic d'això és el de la tomba del vescomte Ramon Folc vi de Cardona, anomenat el Prohom Vinculador, ${ }^{2}$ un conjunt que, com veurem, ha patit successives transformacions al Ilarg del temps, en un Ilarg procés d'entrada gens previsible i en el qual no tots els aspectes es poden donar per resolts. Es tracta d'una obra aparentment ben coneguda, si més no en la seva dimensió estilística, en la mesura que forma part del corpus consolidat d'episodis essencials de l'escultura gòtica catalana, si més no des que Duran i Sanpere, en el seu estudi del 1932 sobre els retaules de pedra -transcendental en la nostra disciplina-, en va precisar la cronologia i el va atribuir al mateix mestre anònim que el retaule $d^{\prime}$ Anglesola. ${ }^{3}$

$\mathrm{Si}$ aquest conjunt ha renovat el seu interès ha estat a partir d'un fet fortuït que ha permès ampliar el seu coneixement material: I'aparició en el mercat d'antiguitats d'un relleu amb un bust de Crist beneint que, per les seves dimensions, material i estil, ha estat identificat per Alberto Velasco no només com a obra del mateix escultor, sinó com una part del mateix sepulcre $^{4}$ (Fig. 1). Efectivament, el fragment encaixa amb precisió en un dels forats que presenta el sarcòfag de pedra, el que se situa a la cara curta sota els peus del jacent, i aquest origen inequívoc en un monument declarat degué incidir en la decisió d'adquirir l'escultura per part de la Generalitat de Catalunya el 2008, pensant en la possibilitat de restituir-la al seu Iloc d'origen. La voluntat de dur a terme la reintegració del vestigi al Iloc d'on fou arrencat i les dificultats que han anat apareixent en emprendre-la són a l'origen d'aquesta recerca, feta per tal de donar suport a l'operació tècnica encarregada al restaurador Albert Gaset i supervisada per Pere Rovira, restaurador del CRBMC, i que va ser executada entre el desembre del 2019 i l'abril del $2020 .{ }^{5}$

La tasca podria, en principi, semblar senzilla: constatada sense dubtes la procedència del fragment, caldria només que aquest recuperés el seu Iloc 


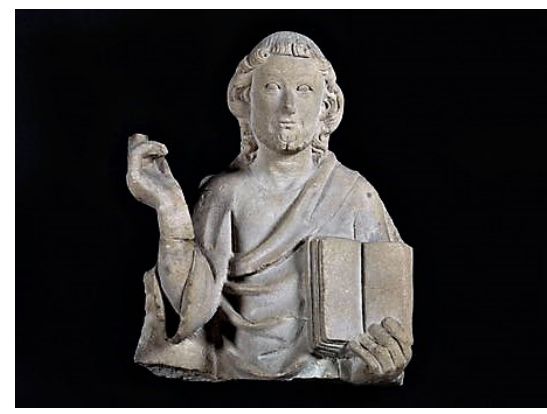

Fig. 1. Bust de Crist arrancat del sepulcre de Ramon Folc VI de Cardona d'origen amb els procediments tècnics adequats per a assegurar la seva estabilitat física i per a reomplir convenientment les mancances de material que fossin necessàries per suturar les diferents parts. Però la mera observació del conjunt funerari, tal i com estava ubicat a la capella de santa Úrsula de I'església del monestir de Poblet la segona comptant des del transsepte de les obertes al costat de I'epístola- permetia constatar que, en el seu emplaçament correcte, el reIleu recuperat quedaria de cara a la paret, separat només un parell de pams del mur del fons de la capella, en una posició invisible per a un espectador normal i del tot inadequada per a una imatge de la significació jeràrquica de Crist (Fig. 2). Es fa aleshores urgent recordar que aquesta ubicació no

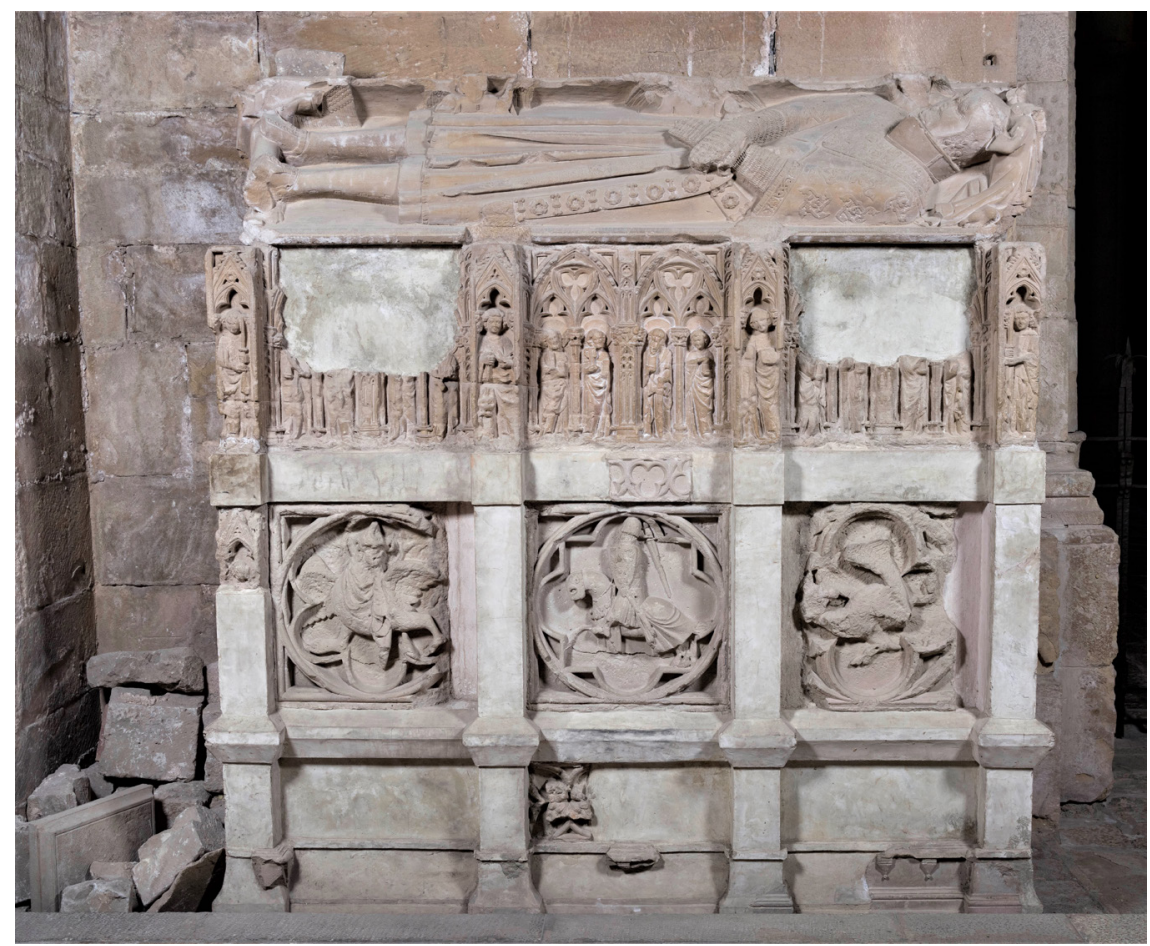

Fig. 2. El sepulcre de Ramon Folc VI de Cardona a la capella de Santa Úrsula de l'església de Poblet de 1933 a 2019 (C) CRBMC Centre de Restauració de Béns Mobles de Catalunya. Fotografia de Ramon Maroto. essencials, que el tema de la relació entre tomba i retaule es reprèn breument a Agustí DuRAN i SANPERE, "L'escultura», dins L'art català, I, Barcelona, 1955-57, p. 353-380, p. 357, mentre que a Agustín DURAN Sanpere i Juan Ainaud de LaSARTE, Escultura gòtica (Ars Hispaniae, VIII), Madrid, 1956, p. 187 i 188 es posen en relació amb les esmentades també altres obres. No és cert, com s'ha dit, que Duran encunyés el nom de Mestre d'Anglesola i, si no m'erro, qui el degué inventar molt després fou Josep Gudiol i Ricart, que I'empra a José GuDIOL, «Arte antiguo y medieval», dins Cataluña, I (Tierras de España), Madrid, 1974, p. 255; ho remarco perquè Duran i Sanpere va assenyalar vincles ben raonables entre obres i en cap moment no va proposar un catàleg del Mestre d'Anglesola del qual distanciar-se, com es pretén a Francesca ESPAÑoL, "El Mestre d'Anglesola», dins L'art gòtic a Catalunya. Escultura I, Barcelona, 2007, p. 8792, p. 91, sense, en canvi, reconèixer a I'historiador cerverí el mèrit de fer el plantejament inicial de la qüestió i el d'agermanar el retaule i la tomba, esmentant-ho com quelcom sabut «des d'antic» (ibidem, p. 88).

4 Alberto Velasco GonzÀLEZ, «Un nou fragment del sepulcre de Ramon Folc VI de Cardona, del monestir de Poblet», Aplec de Treballs, 29, 2011, p. 209-219, amb referències al catàleg de venta.

5 Albert GASET MAJà és I'autor d'una detallada Memòria d'intervenció de restauració i reubicació del sepulcre de Ramon Folc VI de Cardona, el Prohom Vinculador, març del 2020, que dóna tota mena de detalls sobre la 
situació i tractament dels materials del sepulcre i enclou una contextualització històrica que, entre altres fonts, ha tingut en compte algunes de les conclusions que aquí presentem.

6 Jaime FINESTRES Y DE MoNSAlvo, Historia de el Real Monasterio de Poblet, 5 vols, Cervera i Tarragona, 1753-1765. La documentació sobre les obres del segle XVII fou publicada per César MartinelL, La casa de Cardona y sus obres en Poblet (separata de «Estudios y documentos de los archivos de Protocolos», II, p. 53-119), Barcelona, 1949.

${ }^{7}$ No entrarem ara a discutir quina forma és la més correcta per designar aquests nobles, que la GEC anomena Lluís (1608-1670) i Pere Antoni (1611-1690) d'Aragó Folc de Cardona i Córdoba, per bé que el segon fou conegut com a Pedro Antonio Fernández de Córdoba y Aragón i el primer és anomenat Luis Ramón de Aragón Folch de Cardona y Córdoba -o Fernández de Córdobaen diverses fonts hispàniques. Toda comenta els diversos cognoms de Pere Antoni a E. ToDA, Estudis pobletans, Tarragona, 1925, p. 2-3. és I'original del sepulcre, que fou reconstruït en un indret triat arbitràriament en I'època que Eduard Toda dirigia la recuperació i restauració del monument.

Si Toda no va poder refer el sepulcre gòtic al lloc original fou perquè aquest era ocupat des del segle xvir per una nova versió barroca de la tomba de Ramon Folc vi, que va deixar obsoleta la medieval, que aleshores fou reutilitzada per a enterrar-hi el cavaller Rodrigo de Rebolledo. Totes aquestes operacions són ben conegudes, sobretot a partir de I'exposició que, recollint dades de cròniques anteriors, en fa el pare Finestres a la seva fonamental història del monestir de Poblet ${ }^{6}$ Efectivament, a mitjan segle XVII, en una interessant operació encarada a rememorar les glòries passades de la dinastia i a emfasitzar-ne I'antiguitat i I'estatus, els hereus dels vells Cardona medievals, el duc de Sogorb i Cardona i comte d'Empúries, Luís Ramón Folc, i el seu germà Pedro Antonio d'Aragó, virrei de Nàpols, ${ }^{7}$ varen dur a terme un vast projecte de renovació del panteó pobletà, amb la construcció de sengles càmeres sepulcrals sota els dos arcs que sostenen les tombes reials gòtiques, com també l'erecció de noves tombes monumentals per a Alfons el Magnànim -les despulles del qual foren dutes aleshores des de Nàpols- i per al seu germà Enric d'Aragó, avantpassat directe dels Sogorb-Cardona, que ja era enterrat a Poblet sense sepulcre singular. Qui sí en tenia era el Prohom Vinculador, però l'obra gòtica devia semblar indecorosa als ulls dels nobles setcentistes i la seva renovació constitueix una part més d'aquesta empresa monumental. Finestres ho explica així:

«El mismo excelentisimo Señor Don Luis Ramon Folch, Duque de Segorbe y Cardona, no obstante el haver concluido año 1662 los dos sobredichos panteones para sus excelentisimos ascendientes y descendientes, hizo en el año 1669 labrar otro magnifico sepulcro de alabastro de famosas hechuras para el sin segundo y siempre valeroso vizconde de Cardona Don Ramon Folch, Decimo de este nombre, y llamado el Prohom Vinculador (...) El sepulcro, que labraron tambien los dichos escultores de Manresa, Juan y Francisco Grau, por precio de 1800 libras barcelonesas, comienza en el pavimento de el crucero de el lado del Evangelio, y se levanta más de quatro varas entre pedestal, urna y estatua tendida: el pedestal adornado de muchas figuras y primorosas labores. Sobre la urna, rodeada de medios cuerpos grandes y mucha imagineria, se mira la estatua de el vizconde de estatura agigantada, vestido de todas armas. Y toda la fabrica de el sepulcro arrimada a la escalera grande que sube de la Iglesia al dormitorio, que es el puesto mismo donde estava antes el antiguo sepulcro (...) Fallecio este heroico vizconde año 1320, y fué puesto en el sepulcro antiguo en el de 1322, y al trasladarlo al nuevo y suntuoso sepulcro en dicho año 1669 fué hallado su cadàver tan entero como el dia 
de su muerte. Parte de los 347 años que corren desde 1322 hasta 1669 estuvo sepultado en tierra Ilana, y parte en sepulcro de piedra ordinària, en que havia por el rededor esculpido este dístico: Conditus hic sumus Raymundus cognomine Folchus Regibus ecce Comes, Rex Comitique fui» ${ }^{8}$

El contracte de 19 d'octubre del 1667 per a la realització de la nova sepultura especifica que els escultors, "los dits pare i fill Graus, a sos propis gastos, hajan de fer traurer la pedra de la sepultura vella y posar-la y retirar-la de lo puesto se li dirà, y de assentar o fer assentar la obra de dita sepultura en lo lloch hont vuy se troba la sepultura vella de dit senyor Vescomte».9 El trasllat de les despulles al nou sepulcre fou solemnement oficiat el 1669, i fou aleshores quan el vell sarcòfag trescentista fou reutilitzat per a enterrar-hi les restes de Rodrigo de Rebolledo, baró de Monclús, noble de la confiança de Joan II, que

«acabó gloriosamente sus dias en el lugar de Casvas de el reyno de Aragón, por el mes de diciembre de 1479, y traido a Poblet, donde havia elegido su entierro, descansó en tumba de madera hasta el año 1669, que con la ocasión de haver fabricado al vizconde de Cardona Don Ramon Folch el Decimo la insigne sepultura que se descrivió arriba (S.5.num.64) fué colocado en la que el vizconde dejava, que es sepulcro grande de mas de nueve palmos de largo labrado con muchos primores, y estatua vestida de todas armas, tendida sobre la cubierta, que hoy dia persevera puesta sobre el suelo, y arrimado a la pared, frontero a la capilla de N.P.S. Benito». ${ }^{10}$

Com a president del Patronat del monestir Eduard Toda, vinculat a la recuperació de Poblet des de molt abans, va promoure la reconstrucció del sepulcre gòtic. El 1934 Guitert escrivia, en parlar de la capella de santa Úsula i les Verges que «avui es veu allí el monument sepulcral del Prohom Vinculador, darrerament descobert» i reproduïa una fotografia del conjunt recentment refet. ${ }^{11}$ L'any següent el mateix Toda donava notícia d'aquests descobriments, quan explica que, en consolidar el sepulcre barroc del vescomte, molt malmès pels buscadors de tresors que $n^{\prime}$ havien rebentat la base, a més de descobrir alguns ossos del difunt,

«tinguérem la fortuna de trobar els elements de l'urna que faltava al monument, avui completat en tot lo possible. Al verificar allí els descrits treballs, ensopegàrem amb un cert nombre de pedres treballades, perteneixents al primer sepulcre del Prohom, qual part superior, o sien la caixa amb l'estàtua jacent, estava col·locada al peu de I'escala del Campanar, a l'altre costat del creuer, i havia sigut utilitzada com sepulcre d'aquell personal servent
8 J. Finestres, Història..., I, p. 301-302; encara que els cronistes parlen sempre del 1669, data de la col·locació i inauguració de la tomba nova, sabem que I'encàrrec als Grau havia tingut Iloc I'octubre del 1667, i que el març del 1670 encara I'estaven cobrant (C. MARTINELL, "La casa de Cardona...», docs. 14 (p. 92-94) i 27 (p. 109).

9 C. Martinell, "La casa de Cardona...», doc. 14, p. 93.

10 J. Finestres, Història..., I, p. 323-324.

11 Joaquim Guitert I FonTSERÈ, Guia moderna del monestir de Poblet. Troballes d'obres fetes fins l'any 1934, Sant Boi de Llobregat, 1934, p. 54; a la p. 58 es refereix a la tomba barroca i al conegut reaprofitament de la vella.

12 Eduard Toda I GüELL, Reconstrucció de Poblet. Obres realitzades de 1930 a 1934 pel Patronat del monestir. Memòria del president..., Monestir de Poblet, 1935, p. 25-26. Vint anys després Manuel de Montoliu donava notícia del mateix, amb alguns detalls nous i algunes imprecisions, i confirmava la responsabilitat intel-lectual de Toda en I'operació: «El peu del sepulcre s'havia perdut, però fou descobert providencialment entre un munt de runes, gairebé intacte. Immediatament Eduard Toda disposà que s'afegís aquest peu al sepulcre antic i, amb això, la mateixa decoració i el detall central del cavaller esgrimint el seu colossal glavi conten sense paraules la bella Ilegenda...» (Manuel de Montoliu, Llibre de Poblet, Barcelona, 1955, p. 118, reeditat el 1965 a Biblioteca Selecta, n. 182). Ens ocuparem més avall de la llegenda i del cavaller amb l'espasa alçada aquí esmentats. 
13 Gener Gonzalvo, Cartes d'Escornalbou i Poblet. Un epistolari d'Eduard Toda a Agustí Duran i Sanpere (19221940), Tàrrega, 2001, cartes 33 i 34 de les p. 55-56.

14 Sembla que I'operació fou duta a terme als anys setanta o vuitanta, però no se'n diu res a Joan BAsSEgodA NoNELL, Història de la restauració de Poblet, Abadia de Montserrat, 1983, ni tampoc a Andreu Selvat, La restauració de Poblet, (Episodis de la història, 178) Barcelona 1973, que ni tants sols esmenta entre les restauracions dels anys 30 la reconstrucció del sepulcre gòtic del Cardona, potser amb la mateixa voluntat de silenciar I'obra de Toda i de la Generalitat republicana per part d'autors que escriuen durant el franquisme.

${ }^{15}$ Les primeres observacions en aquest terreny formal i material van ser fetes per Albert Gaset al Ilarg del procés d'anàlisi i desmuntatge del conjunt, i va ser ell qui ens les va fer notar durant la visita a les obres en curs; n'ha deixat detallada anàlisi a A. GASET, Memòria d'intervenció.... de Joan II que s'anomenà Rodrigo de Rebolledo. Els elements trobars ens permeteren reconstruir el primitiu monument funerari de I'il.lustre Cardona, col·locant-lo a la segona capella de la nau dreta». ${ }^{12}$

La correspondència que Toda enviava a Duran i Sanpere permet precisar les dates: el 17 de juliol de 1933 el reclama per a que estudiï «una de les escultures acabades de trobar, segle XIV, representant Folch de Cardona, el prohom vinculador, la millor pessa, crec, que tindrem al monestir», i el següent 1 de setembre l'informa que "ya està muntat el monument del Prohom Vinculador. Veniu a veure' $\mid » .^{13}$ Ens referirem més endavant a aquestes escultures descobertes, però el cas és que amb elles i amb les que no calia descobrir fou bastit l'estiu del 1933 el conjunt funerari del vescomte, combinant fragments escultòrics medievals amb una estructura neutra arrebossada, un criteri molt més modern i rigorós que el lamentable pastiche que trenta anys més tard completava Frederic Marés en reconstruir les sepultures reials. Fins a darreries del 2019 el sepulcre del Prohom Vinculador ha estat vist i apreciat per generacions d'estudiosos de l'escultura gòtica sense que mai no hagi estat discutida ni la seva versemblança històrica ni la seva coherència material. Els dubtes i qüestionaments arrenquen de la recent intervenció, punt de partida també d'aquesta recerca. La voluntat de reintegrar al seu lloc el relleu recuperat i de facilitar-ne la visibilitat va suggerir i justificar l'operació de retornar la tomba al peu de I'escala del dormitori, atès que la sepultura barroca ja no era allí, restaurada i desplaçada a la sala de I'abat Mengucho del museu del monestir (Fig. 3). ${ }^{14}$ En aquest emplaçament, avalat per la convicció que es tracta de I'originari, els peus del sarcòfag amb la figura de Crist recuperen la visibilitat presumptament prevista pels creadors trescentistes de la tomba.

El trasllat no d'una peça monolítica o ben cohesionada sinó d'una estructura factícia ha posat en evidència la necessitat d'inventar noves sutures entre els fragments, però també ha suscitat altres problemes més profunds. I és que, un cop desmuntat el conjunt i inventariats tots els elements antics que el configuraven, es van fer visibles certes divergències entre ells. Mentre que I'estil del Mestre d'Anglesola identificable en el jacent i en el sarcòfag es retroba en els muntants amb àngels o en el relleu amb el noble a cavall brandant I'espasa, altres relleus semblen fets en una pedra d'aparença distinta, amb erosions superficials més greus i, a més, amb un motllurat i una figuració d'agermanament problemàtic amb la resta. ${ }^{15}$ Es tracta en particular dels dos relleus de format aproximadament quadrat a banda i banda del compartiment central amb el cavaller, de mides similars als altres dos (fig. 4). El motllurat d'aquests sembla més robust i barroer i, a més, a diferència del central, es tracta de peces netament retallades per 
una o per dues bandes. Sorprèn d'altra banda que el disseny d'un relleu i altre no sigui el mateix -l'un amb tetralòbul dins d'un cercle, I'altre amb sis lòbuls-, i que cap dels dos no coincideixi amb I'emmarcament mixtilini del cavaller. Finalment, les imatges que contenen, molt malmeses, són uns monstres híbrids fets a una escala molt més gran que la resta de la figuració, de la qual potser es podrien diferenciar també estilísticament -encara que els desperfectes dificulten la confirmació d'aquest extrem- i amb la qual és problemàtic establir un vincle iconogràfic coherent amb les tipologies fu-

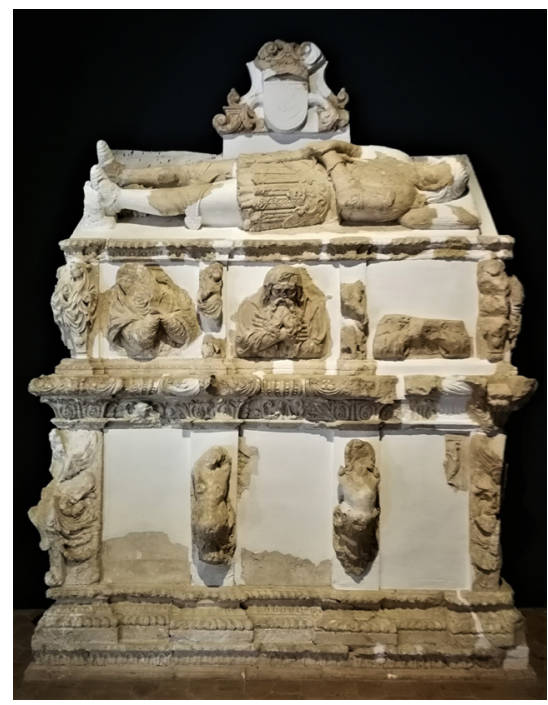

Fig. 3. Joan i Francesc Grau: Sepulcre barroc de Ramon Folc VI de Cardona. 1669
16 Vegeu-ne la enumeració i justificació a l'esmentada memòria d'Albert Gaset.

neràries comparables. De fet, quan es comença a analitzar el conjunt amb mirada crítica, es fa ben evident la seva singularitat tipològica en el context de I'escultura funerària de l'època. Tots aquests indicis, sumats a l'evidència que algun dels fragments menors de tipus arquitectònic fou clarament forçat a entrar en el conjunt, amagant-ne parts treballades, ${ }^{16}$ duen a la conclusió que el muntatge factici promogut per Toda va ajuntar peces no sempre prou coherents en una estructura d'escassa versemblança històrica.

El fet que s'arribés a aquesta constatació un cop I'assemblatge havia estat ja desmuntat i no es tractés, per tant, d'un judici sobre una obra està-

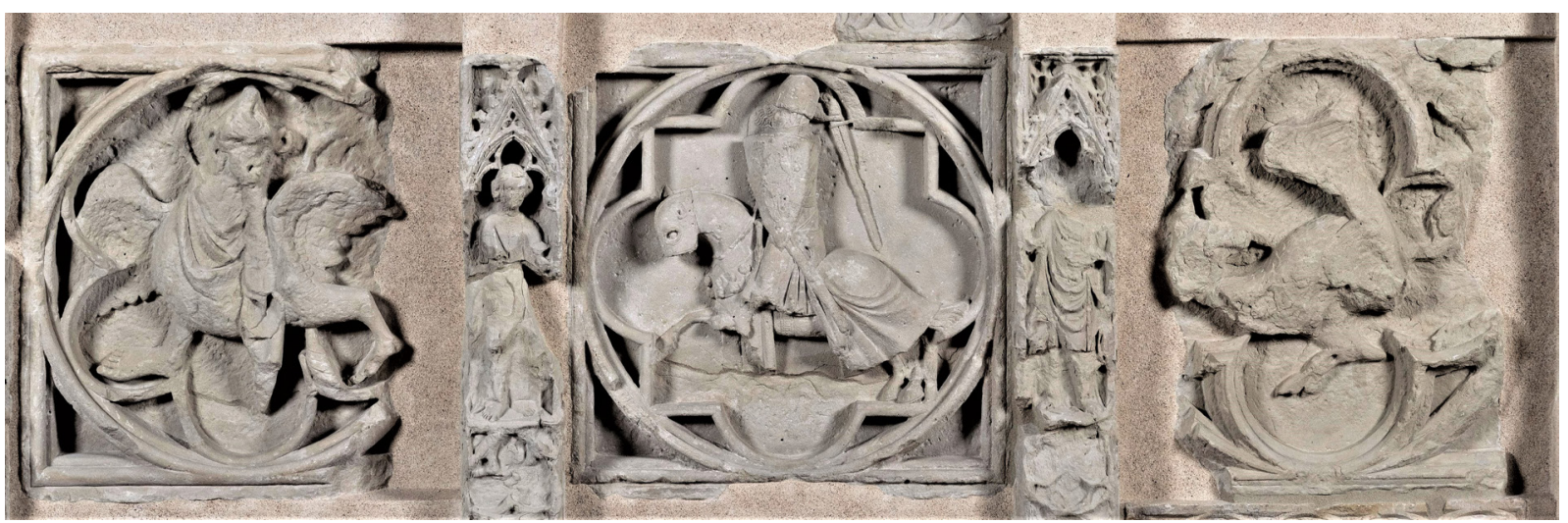

Fig. 4. Registre frontal del sepulcre amb els relleus del cavaller entre els monstres (C) CRBMC Centre de Restauració de Béns Mobles de Catalunya. Fotografia de Ramon Maroto. 
17 Joaquin Guitert FontseRÉ, Poblet. Guia. Notas Histórico-Artísticas del Monasterio. Leyendas y Tradiciones, 2a ed, Barcelona, 1921, làm entre p. 56 i 57 i p. 62. El text i la fotografia són els mateixos en I'edició de 1923 de la mateixa obra, tot i ser maquetada de forma diferent. El mateix negatiu és reproduït amb més claredat i enquadrament més ampli, que permet veure clarament les escales de la porta del cimbori, a Ricardo del Arco, Los sepulcros de la casa real de Aragón, Madrid, 1945, làm. XXIII, identificat com el «Sarcófago primero de D. Ramon Folch de Cardona en Poblet (siglo XIV)», mentre que la fotografia del conjunt ja reconstruït de la làm. XXXI és erròniament retolat com «Monasterio de Poblet. Sepulcro de un infante».

${ }^{18}$ César MartinelL, El monestir de Poblet, Barcelona, 1927, p. 209. Martinell és conscient del caràcter incomplet i de les mancances de I'obra en comentar que «el sepulcre, en ésser traslladat, es desfigurà. Actualment es troba, a més a més, mutilat».

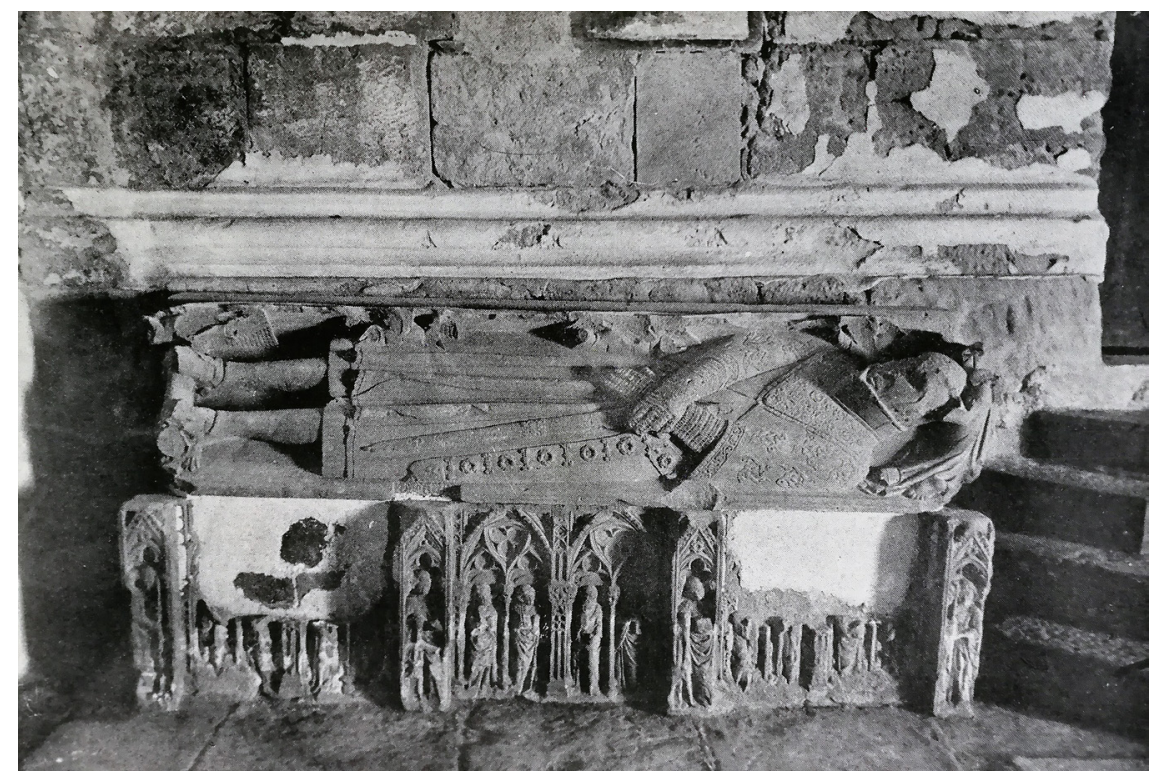

Fig. 5. El sarcòfag i la coberta del sepulcre al peu de l'escala del cimbori abans del 1933

tica sinó d'una reflexió a I'entorn d'una actuació en procés, podia incidir en la presa de decisions sobre la nova reconstrucció. Si Toda va barrejar elements heterogenis i va recrear una estructura inversemblant, hauria estat plausible conservar-la com a testimoni de la mirada i dels criteris d'intervenció d'una certa època, rellevant en la història de I'obra i del monestir. Però una cosa és conservar la proposta i una altra és reproduir-la quan s'ha arribat a la certesa de la seva inexactitud. Calia, per tant, comprovar si I'organització plantejada es podia certificar amb testimonis clars i inequívocs i dilucidar com havia estat realment la tomba gòtica del Prohom abans de la intervenció de Toda i, si fos possible, en el moment de la seva creació.

\section{Mirades retrospectives sobre la tomba: del segle XvI al Xx}

Els testimonis gràfics del segle XIx i d'inicis del xx mostren que aleshores el sepulcre de Ramon Folc de Cardona era format exclusivament per dues peces, les dues més significatives: la coberta amb la figura jacent del cavaller i el sarcòfag amb l'apostolat distribuït entre muntants amb àngels. Així continuava el 1921, quan Guitert en va publicar una foto identificant-lo encara com el Sepulcro de Rodrigo Rebolledo i situant-lo «junto a la puerta que conduce al cimborio», ${ }^{17}$ (fig. 5) i encara el 1927, quan Martinell el veu «tocant a la porta que va al Cimbori, a terra, arrambat a la paret» ${ }^{18}$. Toda, donant per fet que allò 
era només una part del conjunt que ell havia pogut reconstruir, anota el 1935 que aquesta «part superior, o sien la caixa amb l'estàtua jacent, estava col·locada al peu de I'escala del campanar, a l'altre costat del creuer», ${ }^{19}$ referint-se a la banda oposada del creuer nord on era la tomba barroca del Prohom, i a I'indret que d'altres referenciaven amb la porta del cimbori, al mateix braç sud del transsepte on Finestres ubicava el sarcòfag «frontero a la capilla de N.P.S. Benito», I'única capella oberta en aquest sector.

Entre l'anotació del segle xviII i les del xx és necessari afegir-hi algunes informacions aportades al segle xix per assagistes com Pau Piferrer o Valentín Carderera. L'extensa descripció que a les seves Bellezas y recuerdos de España fa Piferrer de Poblet i les seves tombes correspon, malgrat la redacció en present, a I'estat previ a la devastació de 1835, de la qual el text, publicat el 1839, dóna notícia en concloure el capítol dedicat al monestir. ${ }^{20}$ En el seu recorregut diu, en el tocant a l'emplaçament de la nostra tomba: «junto a la [capilla] de san Benito, arrimado a la pared hay un sepulcro de piedra comun, que honraria por si solo cualquier fàbrica (...) està en el suelo, no pegado ni formando parte del muro, sinó tirado allí como un objeto de sobra, y expuesto a servir de apoyo a cuantos pasan». Del sepulcre reutilitzat es limita a comentar la figura jacent del «gigante caballero» amb «tremenda y cumplida armadura», y més genèricament anota que «ricos dibujos e imágenes guarnecenlo por todas partes a la usanza gótica». ${ }^{21}$

Piferrer té més informació sobre les vicissituds del conjunt que no pas Carderera, qui, a la seva famosa Iconografía española, del 1855-1864, afirma: «es el único monumento que conserva su primitiva situación en la Iglesia del insigne Monasterio de Poblet» - una dada errònia perquè n'ignora el desplaçament i la reutilització del segle XVII-, i anota més endavant: «el sepulcro arrimado a un rincón del crucero de la iglesia no descubre más que el lado de los pies y su frontis». ${ }^{22}$ Aquesta precisió sobre I'arraconament que impedeix veure un dels costats curts del sarcòfag contrasta amb el comentari de Piferrer, qui el veia «no pegado ni formando parte del muro». És curiós, en tot cas, que I'arraconament anotat per Carderera en la seva descripció no es reflecteix en el seu dibuix, en què la caixa sembla lliure pels dos extrems (Fig. 6); però, de fet, la fiabilitat de la seva làmina és molt limitada. L'ombra que enquadra el conjunt i que suggereix la forma d'un arcosoli és un mer recurs plàstic completament fictici, ${ }^{23}$ i els greus errors en la plasmació del sarcòfag resulten incomprensibles: ${ }^{24}$ oblida els muntants amb àngels, dibuixa catorze apòstols en lloc de dotze -cosa que I'obliga a esmentar en la descripció els «dos santos desconocidos» que acompanyen l'apostolat- i inventa una distribució il·lògica i estranyament asimètrica de "siete arcadas ojivales poco castizas», que en realitat són sis. Fins i tot es podria pensar que els dos grans forats que rebenten la caixa frontalment, que són a totes les fotografies però no al seu dibuix, ja existien aleshores i van ser obviats en la negligent reproducció de Cardere-
19 E. Toda, Reconstrucció..., p. 25-26. No afegeix res Luís Domenech i Montaner, Historia y arquitectura del monasterio de Poblet, 1927, p. 370 quan anota que «el antiguo sepulcro, deshecho y desfigurado, fue trasladado al brazo sur del crucero».

20 P. Piferrer, Recuerdos $y$ bellezas de España... Principado de Cataluña, Barcelona, 1839, p. 308-309. Sobre I'episodi del 1835, les seves fonts i motivacions vegeu Eduard Riu-BARrera, «Les despulles reials de Poblet, les revolucions i la història», L'Avenç, $\mathrm{n}$. 265, 2002, p. 12-20.

${ }^{21}$ Ídem, p, 253.

22 Valentín CARDERERA Y Solano, Iconografía española : colección de retratos, estatuas, mausoleos y demás monumentos inéditos..., tom I, Madrid, 1855-1864, XVII.

${ }^{23}$ Carderera I'emprarà equívocament en la plasmació gràfica d'altres obres amb un enquadrament tan diferent en la realitat com el sepulcre de la reina Elisenda a Pedralbes; vid. V. CARderera, Iconografía espanyola..., XX, reproduït a Francesca EsPañol BERTRAN, "L'univers d'Elisenda de Montcada i el seu patronatge sobre el monestir de Pedralbes», Lambard, XXV, 2016, p. 9-35, p. 25, que dóna per bones altres fal-làcies del dibuix.

24 Duran i Sanpere ja remarca la poca exactitud $d^{\prime}$ aquest dibuix en fer-ne referència a $A$. Duran i SANPERE, Els retaules..., p. 111, nota 8; cal fer notar que en aquesta obra publicada el 1932, però redactada al menys ja el 1930 (quan obté el premi Massana), no s'hi esmenten, òbviament, els relleus aleshores invisibles descoberts per Toda el 1933. 
${ }^{25}$ Remarquem de passada que sembla poc versemblant la implicació directa d'Alexandre de Riquer en I'episodi de I'arrencament del tors de Crist, plantejada per Velasco quan afirma que "sabem que va participar del pillatge d'elements artístics del monestir» (A. VELASCO, «Un nou fragment...», p. 212). A part del fet de ser els seus descendents els que posseïen I'escultura fins la venda del 2008, la imputació a Alexandre de Riquer es fonamenta en una carta del canonge Jaume Colell adreçada el 1928 a Eduard Toda quan aquest recollia informació per al Ilibre que redactava sobre les malifetes practicades al monestir (Eduard TODA, La destrucció de Poblet, Poblet, 1935); Colell li aclareix que les inicials que figuren en un cert document són les de Pedro Palau González de Quijano (cunyat $d^{\prime}$ Alexandre) i afegeix que «entre els de la colla sembla que també hi figurava I'artista Alexandre de Riquer» (Gener Gonzalvo, Eduard Toda $i$ Güell (1855-1941) i el salvament del monestir de Poblet a través del seu epistolari, Barcelona, 2005, carta 15, p. 83). Però el canonge deu confondre personatges ja difunts, ja que qui estava implicat a darreries del segle XIX en aquestes operacions al costat de Pedro Palau eren els germans Francesc i Manuel Riquer i Carbonell, cosins d'Alexandre, de qui no consta cap vinculació amb les tèrboles actuacions dels seus parents a Poblet. Toda, que havia recollit tota la informació, encloent la que li donava Colell, no I'esmenta per res al seu llibre (vid. E. TodA, La destrucció..., ra. Però també és possible que siguin posteriors a la seva visita a Poblet i perpetrats a darreries de segle, en el context del furor destructiu amb què els buscadors de tresors varen foradar tot el monestir; això si no va ser un espoli intencionat de fragments artístics col/leccionables paral·lel a l'arrencament del bust de Crist dels peus del sarcòfag, deixant in situ també en aquest cas les cames dels personatges desmembrats en la brutal operació. ${ }^{25}$

Foradat o no, en l'esclariment de les característiques originals del sepulcre podem concloure amb els testimonis dels segles XIx i xx que el sepulcre reutilitzat al segle xvir el formaven exclusivament la caixa amb I'apostolat i el jacent al seu damunt i que era arraconat al braç sud del transsepte, on també el situa Finestres al segle xviII, probablement amb el mateix aspecte. El que ell ens diu de la tomba gòtica no és gaire. L'esmenta en parlar del destinatari original, quan apunta:

«EI Vizconde de Cardona D. Ramon Folch el decimo llamado el Prohom, de quien hablan extensamente las historias, murió en la Ciudad de Gerona en el primero de novembre de 1320, y fue depositado su cuerpo en una de las Iglesias de aquella Ciudad hasta el año 1322, que fué frasladado a Poblet, y sepultado conforme a su disposición testamentaria en tierra Ilana, donde

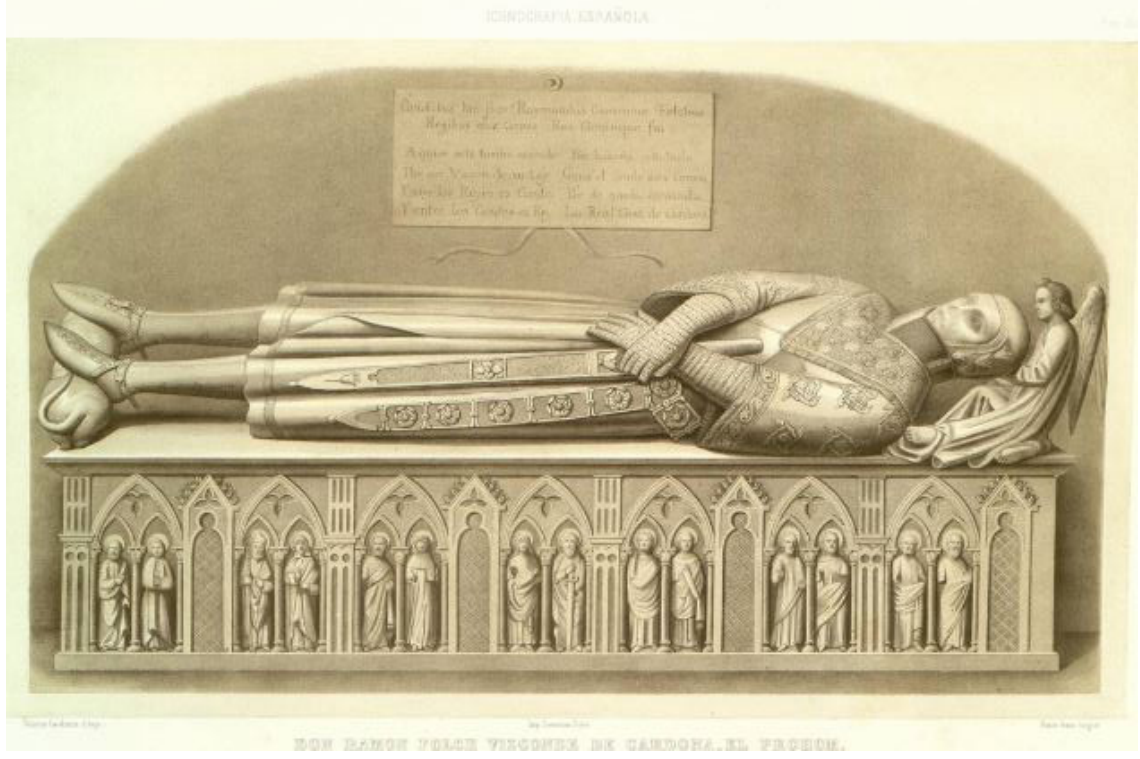

Fig. 6. Valentín Carderera, «D. Ramon Folch, vizconde de Cardona, el Prohom», Iconografía española, tom I, Madrid, 1855-1864 
estuvo algunos años hasta que fué puesto en sepulcro elevado de tierra, y más adelante en otro de alabastro muy suntuoso, donde hoy dia persevera». ${ }^{26}$

Ja hem vist que quan Finestres explica la reutilització de la tomba per al cos de Rebolledo diu: «es sepulcro grande de mas de nueve palmos de largo labrado con muchos primores y estatua vestida de todas armas, tendida sobre la cubierta». ${ }^{27} \mathrm{Si}$ ens atenim al poc que diu, podem concloure que veia el mateix que els testimonis posteriors i també podríem creure que, de fet, tot el que Toda va afegir al sepulcre són parts alienes a ell, sense cap garantia que en formessin part realment. La nova presentació en podria i fins n'hauria de prescindir per tal de no consolidar hipòtesis sense una base sòlida, atenint-nos a aquell conegut principi que declara que la restauració s'acaba quan comença la hipòtesi. El cert, però, és que la tomba que se'ns descriu als segles XVIII i XIX no és l'estructura d’origen medieval sinó la seva versió ja traslladada, manipulada i amputada. Per sort, comptem amb fonts escrites que permeten saber com era el sepulcre, no només abans que Finestres escrigui sinó fins i tot abans que el conjunt gòtic fos desplaçat i substituït per la seva versió barroca. Assenyalar aquests textos i remarcar-ne l'interès, alhora intel·lectual i aplicat, és probablement allò de més interessant $d^{\prime}$ aquest treball.

De fet, no remeto pas a cap font inèdita i oculta sinó a textos publicats fa temps i relativament divulgats. El més conegut és el manuscrit de I'abat Vicenç o Vicente Prada sobre els Sepulcros de la casa real de Aragón, datat el 1678 i romàs inèdit, tot i ser conegut i usat, fins que el 1945 va publicar-lo Ricardo del Arco. ${ }^{28}$ Prada fou abat de Poblet de 1680 a 1684 i es presenta en el manuscrit de 1678 com a indigno monje de dicho real monasterio, en el qual havia ingressat de molt jove i professat solemnement el 1646.29 Si fou així, degué ser testimoni directe de la substitució del sepulcre gòtic pel barroc narrada al seu manuscrit. La seva minuciosa «relación de las demostraciones que [...] se hizieron en la traslación del cuerpo del V. Vizconde Dn. Ramon Folch del sepulcro antiguo en que estava sepultado al nuevo y magestuoso mausoleo» acabat d'enllestir, dutes a terme el març de 1669 davant de tota la comunitat, han de ser redactades a partir de les anotacions d'un testimoni ocular, presumptament el mateix Prada, si ens el creiem quan afirma que: «la traslación del cadáver del sepulcro antiguo al moderno y la forma en que se celebraron las exequias se verá en la infraescrita relación, que se remitió al Exmo Sr. Duque de Cardona Don Luís de Aragón y compuso el escritor de este libro», ${ }^{30}$ és a dir, ell mateix. Prada no diu res sobre el sepulcre gòtic quan explica com el 8 de març van començar "los artifices escultores (que de presente trabaxan en dicho convento) a descomponer el sepulcro antiguo y descubrir el cadáver sacandole de la urna», quedant tots admirats per la seva talla excepcional i la seva p. 265 i ss i $375-376$ ), cosa que no exclou l'interès d'Alexandre per les antiguitats, obtingudes o no a través dels parents; vegeu les precisions familiars a Martí de RIQUER, Quinze generacions d'una família catalana, Barcelona, 2000, p. 1284-1294.

26 J. Finestres, Història..., II, p. 160; torna sobre el tema al vol. V, p. 100-103.

27 Ídem, I, p. 324. En relació amb les característiques de la tomba, ja hem citat més amunt un altre paràgraf en què Finestres diu que el vescomte era enterrat inicialment «en sepulcro de piedra ordinària, en que havia por el rededor esculpido este dístico: Conditus hic sumus Raymundus cognomine Folchus Regibus ecce Comes, Rex Comitique fuì (Idem, vol. I, 303). Aquest epitafi és citat sovint, però Finestres és el primer que dóna a entendre que es tracta d'una inscripció epigràfica que envoltava el sarcòfag. Més que pensar que es tracta d'un element perdut, m'inclino més aviat a creure que es tracta d'un error de l'erudit setcentista, no només perquè no hem conservat cap inscripció en el sepulcre gòtic, que ell devia veure de manera similar a com va arribar al segle $X X$, sinó perquè els antecedents en què ell es recolza i que citarem tot seguit, donen sempre a entendre que l'escrit era en una cartel·la o pergamí extern a I'obra pètria, penjat d'algun indret, com suggereix Vicente Prada quan escriu el 1678 que eren inscripcions "apensas»( R. del Arco, Los sepulcros..., p. 628). Només lectors fidels al peu de la lletra al text de Finestres, com Víctor Balaguer, repeteixen la referèn- 
cia a l'epitafi llatí «grabado en la piedra [que] se leia leía en la primera tumba» del vescomte (noteu el passat del verb llegir, que demostra que Balaguer no veu el que comenta), mentre que «pendiente del sepulcro [...] aparecían en una tabla estos versos castellanos...»(Víctor BALAguER, Las ruínas de Poblet, Madrid, 1885, p. 138). No sabríem si refiar-nos de Carderera quan enclou al seu dibuix la tauleta penjada amb el text dels dos epitafis, el Ilatí i el castellà; vegeu la nostra fig. 6 .

28 El títol que figura a la portada del manuscrit és $S e$ pulcros de la Casa Real de Aragón; Condes de Urgel, Duques de Segorbe, y Cardona; Varones, Señores de vasallos, Cavalleros; Obispos, Abades, y otros muchos, que descansan y eligieron sepultura en el Insigne y Real Monasterio de Nuestra Señora de Poblet, Orden del Cister, elucidados por un indigno monge de dicho real monasterio, fr. V.P.[...] año 1678. Remetem al manuscrit guardat a la Biblioteca Pública de Huesca (Ms 80, consultable a http://bibliotecavirtual.aragon.es/bva/i18n/consulta/registro.cmd? $\mathrm{id}=434$ ) considerat I'original de diverses còpies manuscrites existents a les quals fa referència en transcriure'l Ricardo del Arco (R. del Arco, Los sepulcros..., p. 558-562). L'obra és esmentada de vegades amb el grandiloqüent títol de Palida mors, primeres paraules d'una coneguda sentència $d^{\prime}$ Horaci (Odes, I, 4, 13-14: Palida mors aequo pede pauperum tabernes regumque turres) amb què Prada encapçala el seu manuscrit a manera de lema o motiu. Sobre l'abat Prada, el seu manus- excel-lent conservació. L'endemà «dieron los artifices principio al asiento del nuevo sepulcro», dins el qual es procedí el 4 d'abril a reinstal·lar de nou el cos amb gran cerimonial, durant el qual van «medir la estatura del cadáver por verle tan gigante» $\mathrm{i}$ "se halló que tenia nueve palmos bastantes». És aleshores quan, glossant les excel-lències del difunt, Prada sí fa referència a la tomba vella en el següent i significatiu passatge:

«Dicese que este valeroso varon fué tan esforçado, que no hallando en el mundo iguales fuerças, se alargó a dezir que pelearia con los demonios; y que poco después se halló entre muchas aves como murcielagos, y pretenden eran spiritus malos, que haviendole fatigada mucho le sacaron al fin los ojos, y lo restante de su vida quedo ciego. Algo fabuloso parece la narración, si bien no me atrevo a negarla del todo, porque al pie del sepulcro antiguo de este cavallero, en la parte anterior estava esculpido a cavallo, armado de todas armas, peleando valerosament entre dos murcielagos; y su gran bulto en lo alto de la sepultura tenia los ojos quebrados como de hombre ciego, armado enteramente, y unos angeles coronandole por sus hazañas». ${ }^{31}$

Aquestes singulars característiques de la iconografia de la tomba -0 millor, aquesta singular lectura d'algunes de les seves imatges- és molt interessant, però abans de detenir-nos-hi cal remarcar que el redactat parla en passat en explicar allò que estava esculpido en els relleus. No se'ns diu el que es pot veure, sinó el que es podia veure i, presumiblement, ja no. Qui escriu, per tant, fa memòria, pròpia o aliena, de com era la tomba abans que els escultors la comencessin a descomponer, com diu Prada. Per molt que el futur abat fos presumpte testimoni directe de la deconstrucció del vell sepulcre, la seva evocació a posteriori podria encloure fabulacions llegendàries ja no contrastables amb allò visible en el moment de la redacció. I el mateix es pot dir i accentuar respecte d'altres autors que, sens dubte després de Ilegir el manuscrit de Prada, reprenen el tema en termes similars o literals. ${ }^{32}$

Però més important que la comprovació de qui segueix I'abat Prada i qui no quan la tomba ja no existia en la seva forma original, és esclarir qui segueix ell en parlar-ne; perquè també ell estava parafrasejant una font prèvia. Compareu si no el seu text transcrit més amunt amb aquest fragment d'un altre manuscrit, conegut amb el nom d'Antigualles de Poblet que, en parlar del Prohom Vinculador, afirma que:

«Morí, segons diuen les cartes, ain 1320, en parts molt lluins, emperò no diuen a on. Fonc portat y depositat en la Seu de Barçelona, fins lo ain 1322, quel portaren a Poblet. Fonch cavaller tan valerós, que no trobant home qui 
sel igualàs, se allargà a dir que vinguessin dimonis a pelear ab ell. Poc aprés se trobà entre molts aucells, que mostraven ser rates penades, y pretense que eran dimonis, los quals lo fatigaren en tanta manera, que li tragueren los ulls, y axí restà aprés tota sa vida sego. $Y$ encara que açò pareix faula, emperò no u gose negar de tot, perquè en lo escut questà al peu del dit sepulchre, a la part davant, està lo dir comte armat de totes armes, a cavall, esforçadament peleant ab dos rats penats. Y lo seu gran bulto, en lo alt de la sepultura, te los ulls trencats, com de home sego. En lo cap té corona de Rey, la qual li fonch donada per ses heroiques hazanyes y prohezes». ${ }^{33}$

No ha estat aclarida encara la identitat de fra B.D.L., I'autor de les Antigualles de Poblet, que data el seu manuscrit el 1587 i el signa amb aquestes inicials incertes en un pròleg on reconeix la seva obra deutora de «lo religiós monjo desta sancta casa qui dexà escrit tot lo que recopilat està en lo present volum i altres diversísimes y infinites coses en molts altres que de sa ma ha dexats escrits». Aquesta altra personalitat anònima en què es fonamenta fra B.D.L. ha estat identificada amb fra Martí Marquina, monjo cronista de la casa, autor d'altres textos coneguts i mort el 1586, I'any abans del que figura a les Antigualles. Si, com Prada respecte d'aquestes, fra B.D.L. es va limitar a transcriure un paràgraf de Marquina, el cert és que en I'obra coneguda d'aquest no ha estat identificat el fragment, tot i que sí algun esment poc significatiu de la tomba Ramon Folc de Cardona. ${ }^{34}$

Saber fins a on podem retrocedir en la construcció d'aquest mite seria summament important, però per ara remarquem com de significatiu resulta que estigui ja en vigor el 1587, vuitanta anys abans que el 1667 es plantegi la substitució de la tomba medieval per la barroca. Com de costum, en aquests textos no hi ha cap gran interès descriptiu, i I'autor, que en el seu recorregut per l'església s'ha limitat a anotar que està «en terra una sepultura gran de pedra ben obrada», té molt més interès en parlar-nos del difunt vescomte que de la seva tomba antiga. D'ella només en detalla -a banda de l'epitafi en castellà inscrit en un cartell penjat i que cap autor no oblida de transcriure- les imatges que il-lustren la llegenda de la lluita del personatge amb diables en forma de ratpenat. En el seu redactat, copiat per Prada, es fa èmfasi en la manera com les imatges antigues serveixen per a donar veracitat a un fet que «pareix faula» però que gràcies a elles no es pot descartar del tot.

\section{La reconstrucció d’Eduard Toda del 1933}

Quan Ilegim que «en lo escut questà al peu del dit sepulchre, a la part davant, està lo dit comte armat de totes armes, a cavall, esforçadament pele- crit i les seves còpies vegeu també Agustí Altisent, Història de Poblet, Abadia de Poblet, 1974, p. 508-509.

29 Mossèn Josep Palomer, La decadència de Poblet, Barcelona, 1928, p. 80-81, dóna les dades sobre la joventut de Prada sense esmentar quina font està emprant; tampoc no ho fa R. del Arco, Los sepulcros..., p. 556, que segurament les extreu del text de mossèn Palomer.

30 V. Prada, Sepulcros..., fol 96r (a R. del Arco, Los sepulcros..., p. 626). Finestres transcriu un fragment del manuscrit de Prada relatiu al trasllat del cadàver d'una tomba a I'altra a J. Finestres, Història..., V, p. 100-103.

31 Ibidem, fols. 99r-99v. (ídem p. 627).

32 Vegeu més avall quan ens ocupem específicament de la llegenda i la seva difusió.

33 Antigualles..., fol 19r; usem la transcripció parcial publicada per R. del ARco, Los sepulcros..., p. 449-555 i 484, lleument revisada en acarar-la al manuscrit, conservat a la $\mathrm{Bi}$ blioteca Nacional de Madrid (ms. 1701) i consultable on line a http://bdh-rd.bne.es/viewer. $v m ? \mathrm{id}=0000013316$ \&page $=1$.

34 Joaquim Guitert I FonTSERÉ, Col/lecció de manuscrits inèdits de monjos del reial monestir de Santa Maria de Poblet, transcrits per..., 9 vols, Barcelona, 1947-49), 1, p. 22: «En la tomba que està al peu del dormidor està Ramon Folch, biscomte de Cardona, lo qual té aquest títol en laor sua:...», i transcriu a continuació I'epitafi en vers que cap autor antic descuida. 
${ }^{35}$ Així ho afirma Mn. J. PALOMER, La decadència..., p. 97; sabem també per la seva correspondència (vegeu G. GonZALvo, Eduard Toda i Güell i el salvament..., p. 104, carta 43) que als anys trenta Toda va promoure una fallida publicació del manuscrit per part de I'Acadèmia de la Història de Madrid amb pròleg de Ricardo del Arco, que seria qui molt després n'enclouria finalment la transcripció a la seva obra repetidament citada. ant ab dos rats penats», el lector atent haurà endevinat ja fa estona que el guerrer a cavall dins un escut no pot ser altra cosa que el relleu que Toda va col·locar a la part baixa de la seva reconstrucció del sepulcre (Fig. 7). Un fragment que Finestres no esmenta ni comenten Piferrer i Carderera -tan amant aquest d'armes i armadures-, ni cap altre autor del XIx, malgrat el detallisme de la figura al galop, que branda un escut amb els cards dels Cardona i alça enèrgicament l'espasa. Els seus antagonistes no poden ser altra cosa que els «aucells, que mostraven ser rates penades, y pretense que eran dimonis», és a dir, els éssers monstruosos representats en els plafons que són a banda i banda del cavaller (Figs. 8 i 9). Per si quedés algun dubte que ens estan parlant del mateix sepulcre que ens ocupa, podem comprovar com, en efecte, la seva figura jacent «te los ulls trencats, com de home sego», un detall que, aquest sí, Carderera no va oblidar de plasmar en el seu dibuix ni, com veurem, al seu text.

No va advertir, en canvi, ni la presència del cavaller ni la dels monstres visibles al segle XviI, desapareguts presumptament el 1669 i descoberts el 1933, quan Toda els integra en la restauració del sepulcre que, d'aquesta manera, sembla efectivament haver retornat a la seva forma primigènia. Encara que ens mancaria una memòria detallada de I'operació de 1933 que explicités quines fonts usava Toda per a orientar la seva reconstrucció i quin era l'origen exacte dels fragments fins aleshores no contemplats, tenim prou informació per a reconstruir aquestes coordenades. Pel que fa a la primera qüestió, sabem que Toda -que estava constantment assessorat en aquests afers per Duran i Sanpere- posseïa una de les còpies del manuscrit de Prada ${ }^{35}$ i és possible que també conegués les Antigualles. Respecte a I'origen dels materials, ja hem vist com ell mateix va donar notícia del descobriment d'algunes pedres treballades en reparar la base de la tomba del segle XVII i de la seva convicció que havien de ser elements de la tomba gòtica, fins aleshores invisibles pel fet $d$ 'haver estat reutilitzats com a material de construcció pels artífexs del nou sepulcre. Això explicaria, a més, el retallat dels dos plafons amb monstres, adaptats sense miraments a la seva nova funció estructural pels Grau, els mestres encarregats no només de fer les noves escultures, sinó també de «descomponer el sepulcro antiguo» el 8 de març de 1669 i començar l'endemà «al asiento del nuevo sepulcro [...] que se acabo de asentar a 24 de março del sobredicho año 1669». En quinze dies els Grau basteixen la base d'una estructura alta que sembla voler imitar la volumetria del conjunt previ-, la revesteixen dels elements que ja tenen tallats i col-loquen al damunt el nou sarcòfag i el nou jacent. El basament massís es construeix amb materials diversos, entre els quals bona part dels que procedeixen de la tomba vella, exceptuant els preservats per a la seva reutilització, en principi només els sarcòfag i el 
jacent gòtics. La resta, retallada i fragmentada, roman invisible fins la destrossa del basament i la posterior intervenció de Toda que, amb els fragments descoberts i potser també $d^{\prime}$ altres recuperats dels museus de Tarragona, ${ }^{36}$ «inventa» un conjunt que s'adiu amb tot el que els textos antics permetien saber.

Amb aquesta conclusió provisional s'aclareix el principal dubte plantejat durant la nova reconstrucció: el que Toda va organitzar a la capella de Santa Úrsula no és una invenció arbitrària i per tant resulta legítim avui dia refer una estructura similar a aquella, atesa la seva veracitat històrica, suficientment fonamentada en documentació antiga. El nou muntatge reintegra totes les parts del sepulcre que Toda havia emprat, a més del relleu adquirit el 2008 i alguns fragments més que, dipositats als magatzems del monestir, han pogut ser identificats i reubicats gràcies a la perícia d'Albert Gaset i les cer-

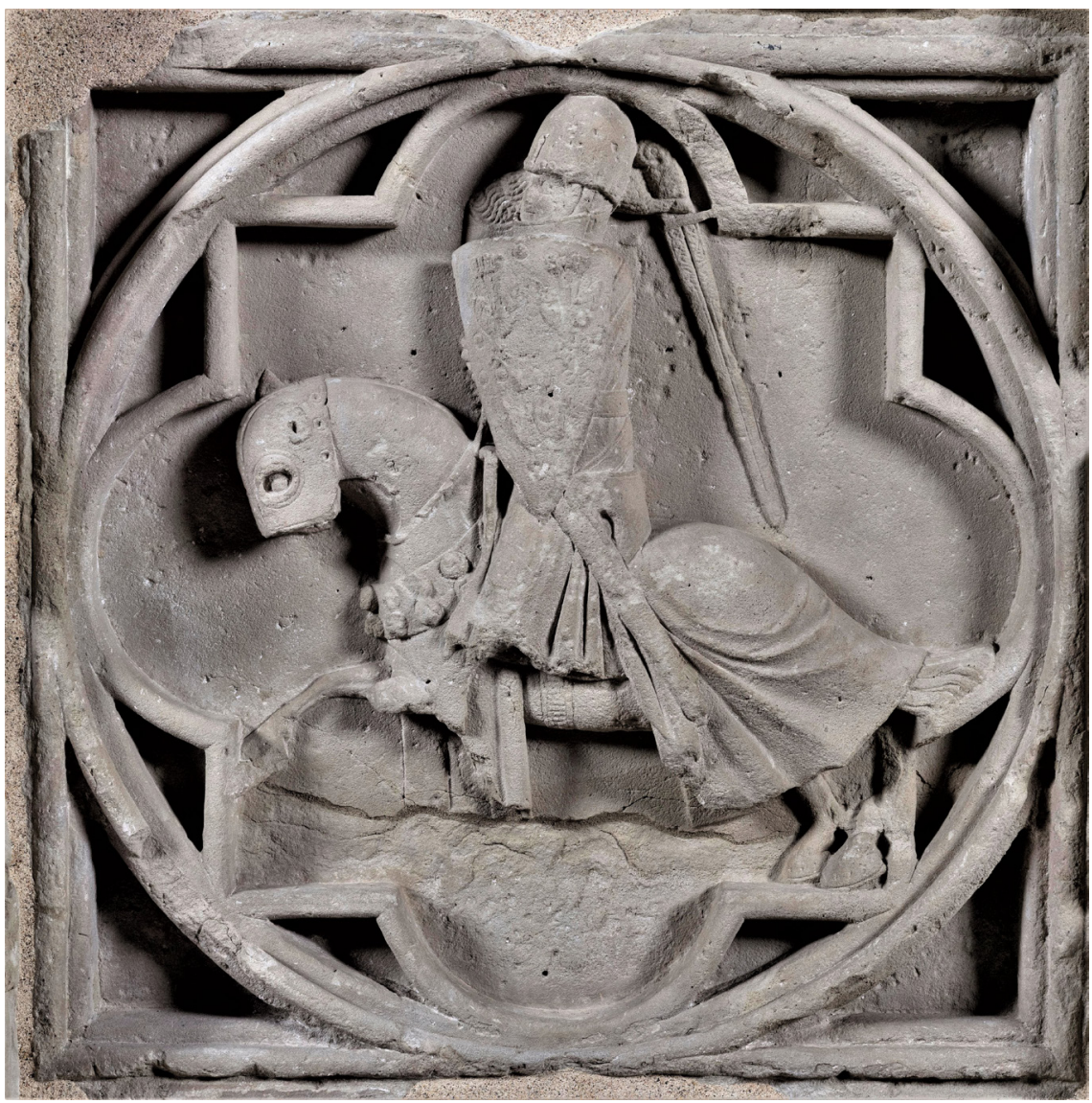

Fig. 7. Cavaller amb escuts Cardona al plafó central del cos baix del sepulcre (C) CRBMC Centre de Restauració de Béns Mobles de Catalunya. Fotografia de Ramon Maroto.
${ }^{36}$ Entre les escultures que havia pogut reconstruir amb fragments recuperats del museu de Tarragona, on eren des de 1854, Toda esmenta en una acta del març de 1934 el sepulcre de Prohom Vinculador, sense que quedi clar si s'està referint a la tomba gòtica o a la barroca (Eduardo Toda y GüELL, Panteones reales de Poblet, Tarragona, 1935, p. 93). És plausible que en el seu interès en reivindicar per a Poblet els fragments que en mala hora en van sortir, es procurés fer-ne cabre en la reconstrucció algun que ha resultat ser aliè a l'empresa, però també que no s'hi trobés lloc per a algunes de les peces recuperades, que van romandre en el lapidari pobletà i que ara sí s'han pogut reubicar en la tomba. 
37 Vegeu els gràfics amb la indicació dels nous fragments incorporats a la tomba a A. Gaset, Memòria d'intervenció.., p. 27-28. El fragment que resta al marge de les reconstruccions de 1933 i 2020 és un caparró de pedra conservat al Museu Marès de BarceIona i que, en base a les dimensions, el material i l'estil, ha estat identificat com a part d'un dels àngels acèfals que envolten el jacent a Francesca ESPAÑOL, "Atribuïble al Mestre d'Anglesola. Cap d'àngel». Dins: Catàleg d'escultura i pintura medievals: fons del Museu Frederic Marès. BarceIona, 1991, p. 329-330; la hipòtesi, ben atractiva, manca encara d'una comprovació i confirmació material.

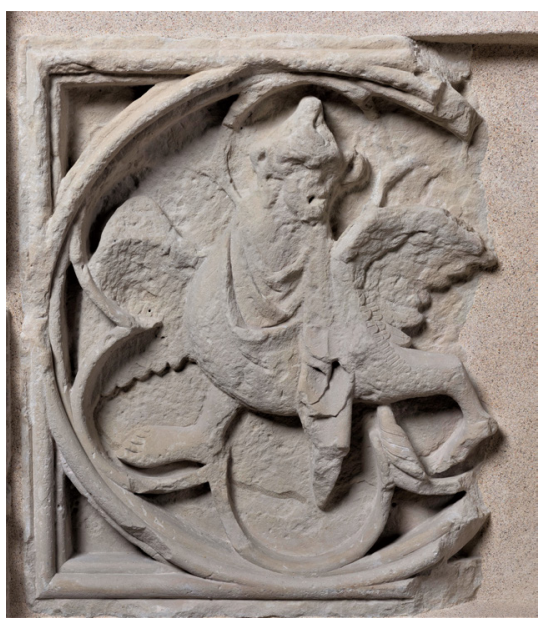

ques de Damià Amorós, director del Museu de Poblet. ${ }^{37}$ A més, la nova presentació, que recupera el Iloc on havia estat la tomba, al peu de l'escala del dormidor, permet continuar explicant la història del cavaller cegat pels dimonis en forma de ratpenat que la seva arrogància guerrera havia invocat (Fig. 10).

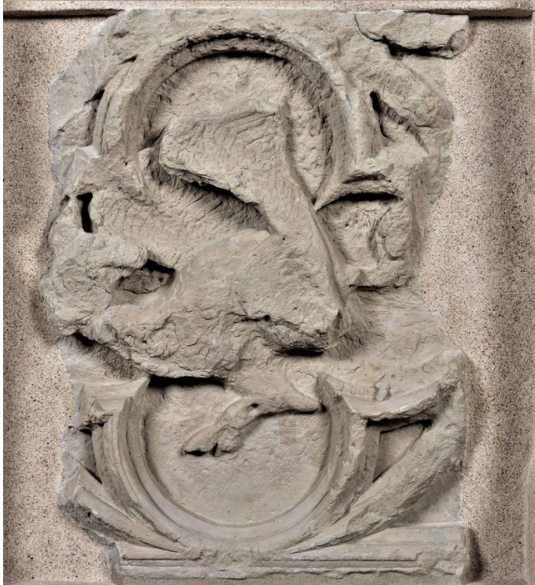

Fig. 8 i Fig. 9. Monstre al plafó lateral del cos baix del sepulcre (C) CRBMC Centre de Restauració de Béns Mobles de Catalunya. Fotografia de Ramon Maroto.

\section{Agressions al vescomte i mutacions de la tomba}

Ara bé, aquesta refacció del conjunt que agrupa tots els fragments gòtics difícilment pot ser identificada amb la tomba que el Mestre d'Anglesola va esculpir per a enterrar-hi Ramon Folc de Cardona alguns anys després de la seva mort el 1320. En absolut és versemblant que un noble trescentista es fes una tomba per a ell o els seus avantpassats subratllant com a únic esdeveniment representat de la seva vida -i el sol fet de representar-ne un ja és prou estrany- l'episodi en què es posa en evidència la seva supèrbia i el càstig rebut per ella. Un càstig, el de la ceguesa, que s'evocaria a més en la forma com es representa el seu rostre sense ulls. No té la més mínima versemblança la idea

que I'aspecte mutilat del rostre del vescomte sigui una realització intencionada de l'escultor gòtic i qualsevol observador entès comprendrà que l'obra ha estat víctima d'una agressió deliberada, un tipus de damnatio memoriae que, de sempre, s'ha acarnissat amb el cap, la cara i, especialment, els ulls de les representacions dels personatges a qui es vol denigrar (Fig. 11). Goso avançar la sospita que la faula, de la que no tenim testimonis medievals, va ser inventada per espectadors imaginatius suggestionats per les imatges posades davant dels seus ulls, amb les seves incongruències i els seus desperfectes.

MATÈRIA 18-19 


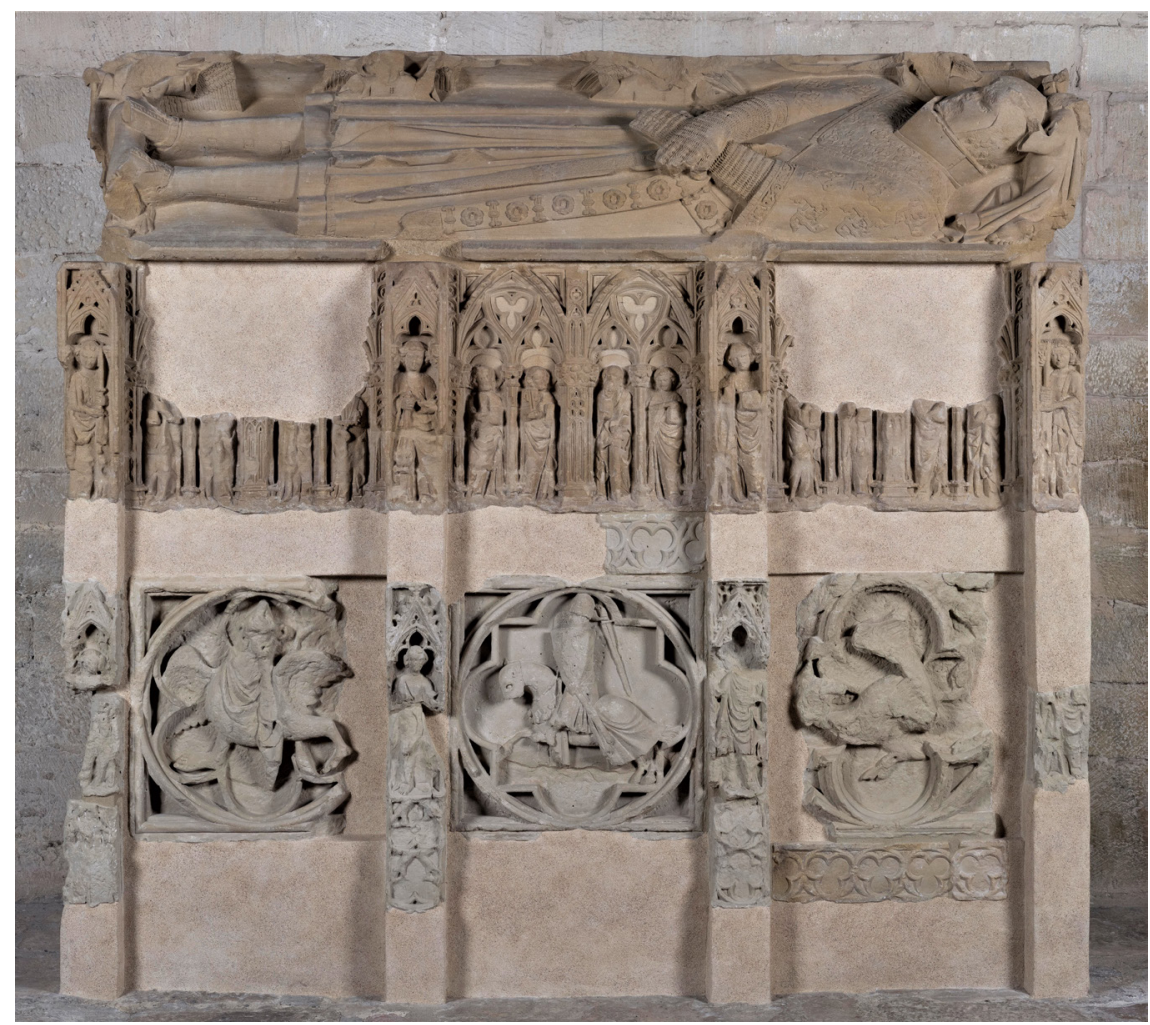

Fig. 10. El sepulcre de Ramon Folc VI de Cardona restaurat i reubicat el 2019-20 C CRBMC Centre de Restauració de Béns Mobles de Catalunya. Fotografia de Ramon Maroto.

Limitem-nos per ara al més evident i millor documentat d'aquests desperfectes: els ulls repicats del jacent. Ja ho estaven quan els va dibuixar Carderera, però no els podem relacionar amb les malvestats anticlericals del 1835 ni amb la posterior vandalització del monestir perquè el detall de «los ojos quebrados» és esmentat per Prada i, abans, per I'autor de les Antigualles el 1587. Ja aleshores el sepulcre havia estat intencionadament malmès, si més no en aquest tocant i potser en algun més que els cronistes no saben o no troben tan adient esmentar. Però si la situació ja era aquesta abans de I'exclaustració del 1835 i abans de la guerra dels Segadors al segle xviI, de la de Successió al XviII, de les carlinades del XIX i de la civil espanyola al Xx, cal preguntar-se en quin moment va poder tenir lloc un tal atemptat a la memòria del vescomte. No ens consta cap episodi de saqueig o agressió directa del monestir entre I'execució de la tomba als anys 20-30 del segle XIV i el 1578. És cert que durant la guerra dels Dos Peres, entre el 1356 i el 1369, el Cerimoniós va témer que les tropes del rei de Castella o les del pretendent Enric de Trastàmara, aleshores aliat seu, poguessin perjudicar Po- 
${ }^{38}$ A. Altisent, Història..., p. 272 i 296-313; Altisent apunta que durant la dècada de 1360 «els dominis dels encontorns de Poblet, i potser el mateix monestir, havien sofert ja el pas de les companyies en els conflictes peninsulars» ( $p$. 297), però el cert és que no hi ha testimoni que confirmi malvestats que afectessin directament el monestir.

39 La cita prové de Santiago Sobrequés I Vidal i Jaume Sobrequés I CALlicó, La guerra civil catalana del segle $x v$, vol.. 2, Barcelona, 1973, p. 210, dins un capítol (pp. 209-227) procedent de Jaume SOBREQUÉS I CALLICó, «L'actuació política de l'abat i del monestir de Poblet durant els primers anys de la guerra civil catalana (1460-1464), a I Col.loqui d'Història del Monaquisme Català, Santes Creus, 1966, vol. II, Santes Creus, 1969, p. 207-264; Vegeu també sobre I'afer A. Altisent, Història..., p. 405-412.

40 A. Altisent, Història..., p. 408. blet, i per aquest motiu el 1363 va escriure a aquest darrer advertint-lo de la seva protecció sobre el monestir, al qual «volia preservar de tota injúria, dany, violència i ofensa». És en aquest context que el 1368 s'emprèn la fortificació de Poblet amb una muralla que estaria en obres unes quantes dècades, durant les quals no van faltar altres ocasions de perill, malgrat que no consta que aquest es materialitzés mai en agressions reals al conjunt. ${ }^{38}$

Tampoc no hi ha constància que aquestes tinguessin Iloc durant la Ilarga guerra civil del segle xv (1462-1472), per bé que la implicació de personalitats pobletanes en alguns dels esdeveniments del conflicte podria tenir alguna cosa a veure amb les nostres cabòries. La situació degué ser complicada dins el monestir a l'inici de la guerra,

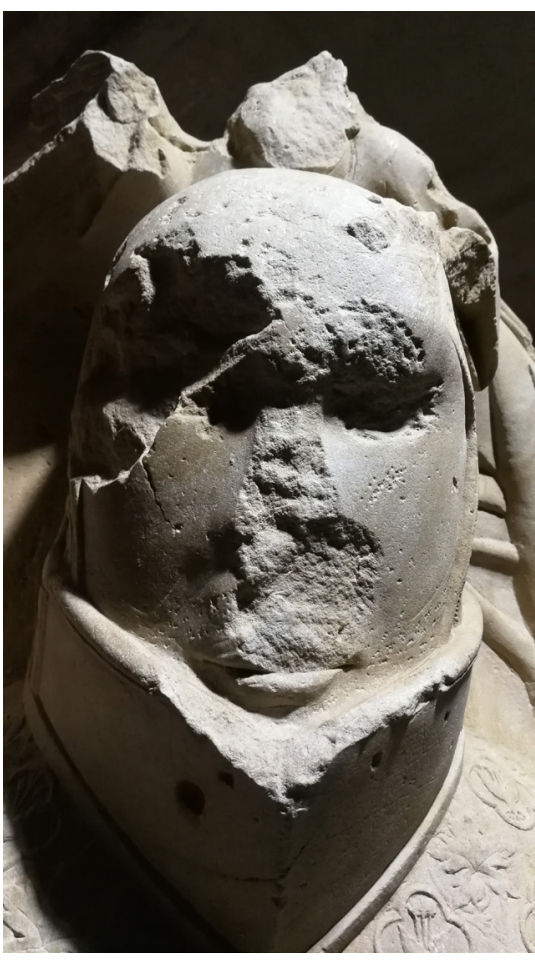

Fig. 11. El cap de la figura jacent del vescomte amb el ulls i el rostre trencats entre el 1462 i el 1464. Per dir-ho breument i en paraules de Sobrequés, durant aquest temps «la comunitat havia negat I'obediència al seu abat i seguia la causa dels rebels, mentre que I'abat era un dels més ardents defensors de Joan II». ${ }^{39}$ Efectivament, Miquel Delgado, d'origen castellà, era abat de Poblet des del 1458, i, malgrat la seva estreta familiaritat amb el rei, abans de I'inici del conflicte armat era al costat de la Diputació del General en les reivindicacions davant del monarca. Però un cop el trencament es precipita i el juny de 1462 el rei és declarat enemic del Principat, el 30 d'aquell mateix mes I'abat Delgado, "després de nomenar al monestir un vicari per a presidir la comunitat, a mitjanit feu el pas decisiu i, abandonant Poblet (on devia veure que els monjos es decantaven pel govern de Barcelona), passà activament al costat de Joan II». ${ }^{40}$ EI nomenament d'un vicari, sotmès a un consell d'ancians, però al marge del prior, qui va presentar-se a Barcelona a reclamar, ja fou un primer moment de fricció en absència de I'abat, però Poblet sembla haver-se mantingut fidel a la Generalitat fins que els triomfs militars del rei permeteren que el juliol del 1464 Delgado tornés al monestir i que aquest restés dins I'òrbita reialista fins a la fi de la guerra, el 1472. 
No podem resseguir ni totes les dades d'aquest moment d'incerteses ni les especulacions interpretatives al seu voltant, però no costa gaire imaginar la tensió i els enfrontaments dins del monestir, si més no en aquest període de dos anys d'absència de l'abat. Encara que no atestada documentalment, és plausible creure en l'existència entre els monjos de Poblet d'una facció extrema contrària a Joan in i als seus aliats capaç de dur a terme algun gest visible. Tot i que el monestir servava ja manifestacions evidents de la nova dinastia Trastàmara, començant per la tomba del rei Ferran I, pare de Joan II -la tomba d'aquest no es faria fins molt després, per encàrrec del seu fill Ferran II-, atemptar contra un sepulcre reial havia de semblar massa greu i, alhora, massa ardu, atesa la col·locació dels sarcòfags reials damunt els grans arcs trescentistes. Alternativament, una de les figures que més podia concitar I'odi antireialista era Joan Ramon Folc III de Cardona -aleshores conegut com a comte de Prades perquè el títol de comte de Cardona I'ostentava el seu pare, encara viu- el noble més fidel i actiu a favor dels interessos de la corona fins el punt que, de nou en paraules de Sobrequés, «des del moment de començar la guerra fins al seu acabament, el comte de Prades fou potser la màxima personalitat militar del bàndol joanista». ${ }^{41}$

És versemblant que el bel·licós aristòcrata fos percebut en algun moment com a digne successor del Prohom Vinculador, famós també pels seus fets d'armes i per la fidelitat al rei en l'episodi del setge de Girona del 1285. Que la seva tomba, molt més assequible i vetusta que les dels reis d'Aragó, hagués estat aleshores víctima substitutòria a l'abast de la fúria dels adversaris del seu descendent és una opció plausible, per bé que del tot conjectural. És suggestiu, encara que segurament massa novel-lesc, imaginar que un reduït i agosarat grup de monjos va trobar ocasió per escolar-se més o menys furtivament a l'església, es va enfilar al túmul -cosa fàcil si ja era arran de I'escala del dormidor on torna a ser- i va repicar amb fúria iconoclasta els ulls, el nas i la boca del jacent com a manera de manifestar I'aversió contra el Cardona contemporani, contra el fugit i reialista abat Delgado i contra Joan II en darrera instància. No podem atestar que en el mateix moment es mutilessin altres elements del conjunt, però potser sigui significatiu que el gran escut dels Cardona que, just rere el cap del jacent, apareix al nivell més alt de la cara lateral de la tomba, hagi estat raspat fins fer desaparèixer gairebé del tot el relleu amb els cards (Fig. 12). És clar que l'escut apareix a més llocs, però aquest és el més gran de tots els que, si més no en l'actualitat, figuren a la tomba. ${ }^{42}$ Altres desperfectes podrien haver tingut Iloc, però el fet que alguns vestigis hagin estat retrobats al segle $x x$ en col·leccions privades $s^{\prime}$ ha de relacionar més aviat amb fractures fetes per mans vuitcentistes interessades en les antiguitats. Tot i així, no es pot descartar que es
41 S. Sobrequés, Els barons..., p. 191.

${ }^{42}$ No ens passa per alt que I'intent d'eliminar el gran escut Cardona hauria pogut ser efectuat al segle XVII en el moment de reutilització de la tomba per a Rodrigo Rebolledo. 
produïssin a la tomba altres danys, fins i tot estructurals, que obliguessin a reconstruir-la un cop recuperada la calma a la casa, potser després del retorn de I'abat Delgado el 1464, o més tard i tot, acabada la guerra el 1472.

Si plantegem la possibilitat d'una reparació àmplia és perquè, encara que obviem tant els desperfectes iconoclastes sobre el jacent com els forats dels cercadors de tresors o les mutilacions dels col-leccionistes, el conjunt resultant continua sense oferir una imatge convincent com a sepulcre gòtic coherent i obliga a especular de nou ja no sobre pèrdues sinó sobre incoherències i recomposicions. Ens cal tornar sobre observacions materials i estilístiques ja anotades des del començament. Ni I'escala, ni la iconografia, ni la conservació ni, potser, l'estil agermanen convincentment els tres relleus frontals que els cronistes interpretaven com el combat entre el vescomte i els dos dimonis-ratpenats (Fig. 4). I si en el tocant als desperfectes més grans que afecten els dos relleus amb monstres podem recordar les manipulacions i el maltractament en esdevenir material constructiu (Figs. 8 i 9), no podem deixar de preguntar-nos perquè això no afecta el relleu amb el cavaller, envoltat de traceria distinta i més delicada (Fig. 7). Malgrat que no falten monstres marginals al retaule d'Anglesola, I'altra obra lligada a la mateixa autoria que el sepulcre, els que es veuen als minúsculs capitells dels arcs que separen escenes (Fig. 13) mai no tenen ni les dimensions ni el protagonisme que endevinem en les dues malmeses figures, on res no permet constatar les subtileses del mestre. En resum, ens inclinem a creure que foren incorporades al sepulcre del Prohom Vinculadoren un moment posterior a la seva creació a l'entorn del 1320-1330 i anterior a la descripció del 1587, sigui o no en el context de la guerra civil, que he mirat d'argumentar com el més plausible per a una manipulació d'aquesta mena.

Del cert, però, no sabem ni el moment exacte ni el perquè precís de la transformació, ni tampoc l'origen dels elements espuris ni la forma inicial del sepulcre del Cardona que, d'altra banda, és difícil d'acceptar que fos la que ens han llegat els segles i $s$ 'ha respectat en la recent recomposició dels diversos fragments. En aquest punt caldrà subratllar l'interès d'aquesta operació tant per la reintegració del Crist novament adquirit (Fig. 14) com per la recuperació

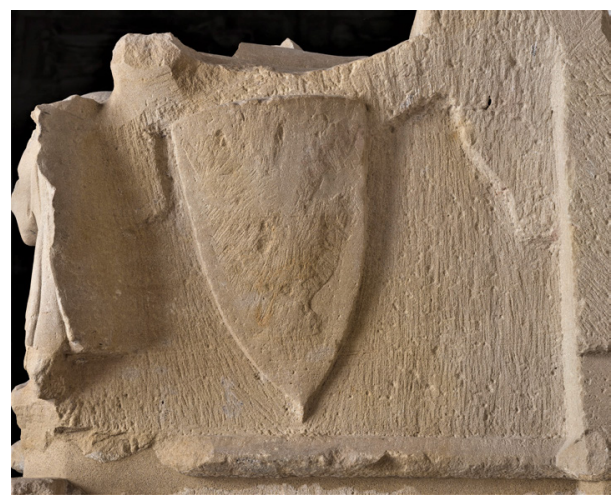

Fig. 12. Escut dels Cardona raspat a la capçalera del jacent. (C) CRBMC Centre de Restauració de Béns Mobles de Catalunya. Fotografia de Ramon Maroto. 
de la ubicació antiga del conjunt i la revisió de tots els seus elements coneguts. A més, com ja hem esmentat, en el context d'aquest examen han estat rebutjades algunes parts espúries i, sobretot, han estat incorporats altres fragments esculpits fins ara no identificats com a parts del sepulcre. Entre aquestes destaquen els muntants més o menys fragmentaris amb figures d'àngels 0 acòlits (Fig. 15), equivalents als que separen els tres grups de quatre apòstols de I'enfront del sarcòfag, i que ara han estat reubicats separant els tres relleus del cos baix, amb el cavaller entre els dos monstres. També és una nova incorporació remarcable I'assemblatge a partir de diversos trossos d'un plafó amb tres escuts dels Cardona sota arquets i entre muntants, que han estat emplaçats de manera prou versemblant en una de les cares curtes de cos baix, la que correspon a la capçalera del túmul (Fig. 16), com també altres elements de traceria incorporats a la cara curta contrària (Fig.17).

La bona correspondència estructural dels elements no obsta per a què experimentem una certa perplexitat enfront una cara lateral amb la superposició de fins a tres registres d'escuts: a la part baixa, els tres escuts petits ben articulats amb traceria (Fig. 18); al capdamunt, l'escut raspat, gran, allargassat i estranyament inclinat (Fig.12); i entremig, en la cara del sarcòfag oposada a la que, als peus, enclou la figura del Crist ara reconstruïda, un altre escut de grans dimensions dins un tetralòbul encerclat (Fig. 19). Els tres nivells d'escuts superposats mostren una organització que sembla reiterativa i discordant, a escala diferent i amb emmarcaments de traceria ben distinta, tant en el disseny com en l'execució. Aquestes irregularitats ens retornen a

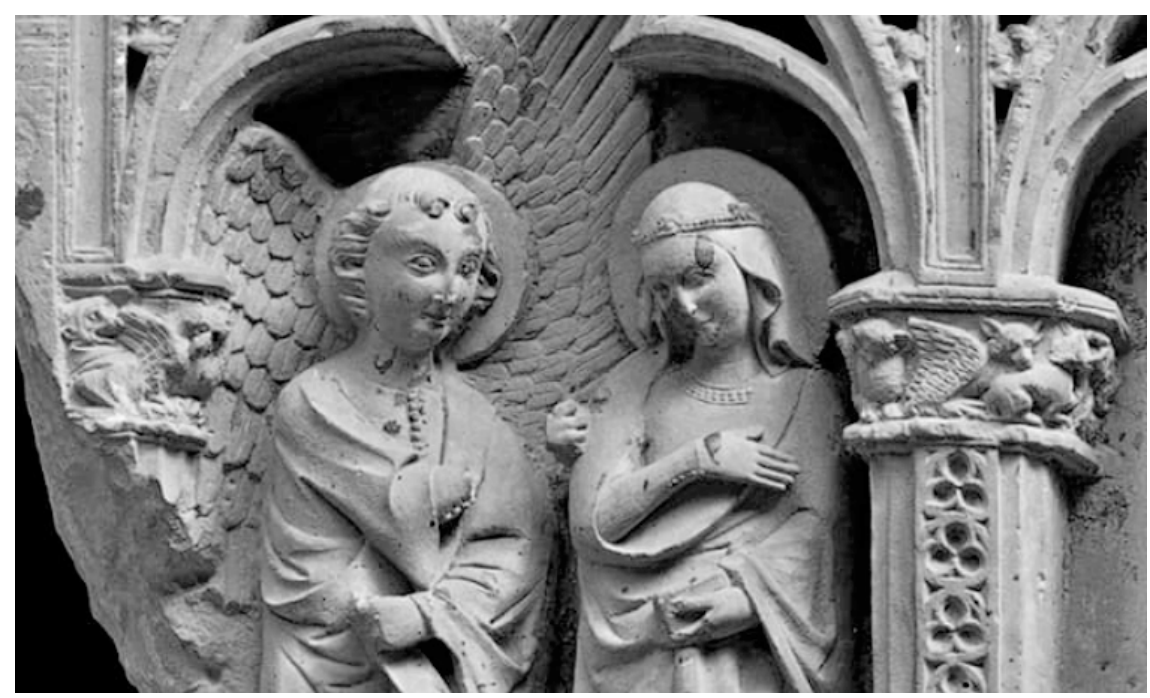

Fig. 13. Anunciació del retaule d'Anglesola amb monstres als capitells. Museum of Fine Arts, Boston 


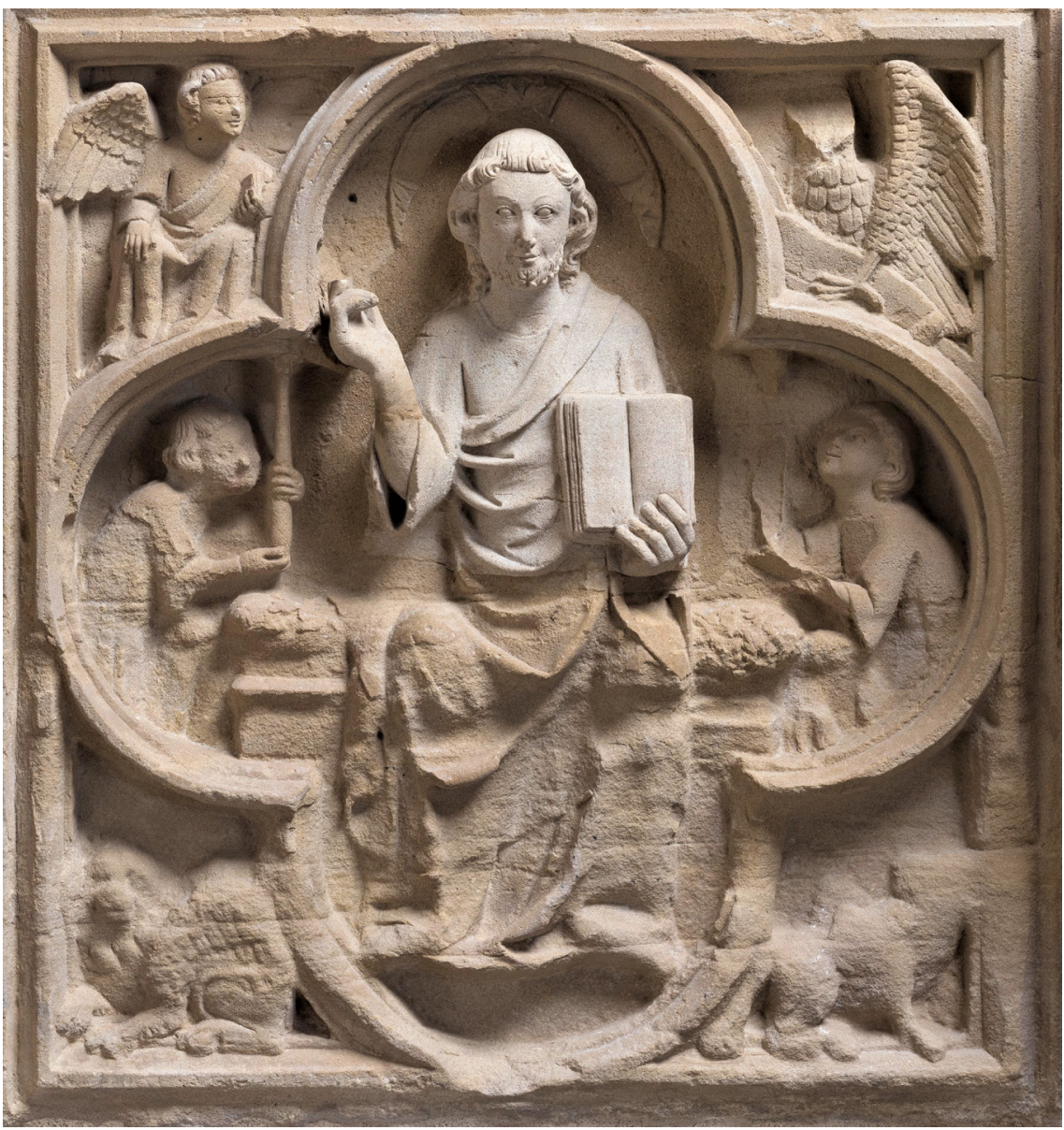

Fig. 14. Bust de Crist reubicat als peus del sarcòfag (C CRBMC Centre de Restauració de Béns Mobles de Catalunya. Fotografia de Ramon Maroto.

les suspicàcies inicials sobre la coherència de tots els elements del conjunt. $\mathrm{Hi}$ afegirem encara, amb prudència, certs dubtes a l'entorn de l'escut a un extrem del sarcòfag, força deteriorat i gran -l'escut més gran de tots els visibles ara a la tomba, juntament amb el del seu damunt-, ja que no és fàcil veure-hi bé I'heràldica pròpia dels Cardona. Els elements fragmentats recoberts d'incisions que es veuen a la seva part alta no s'adiuen bé amb les flors dels cards característics i l'únic detall significatiu per mirar d'endevinar-los són els cinc punts excavats a la part baixa de l'escut, que coincideixen amb el disseny emprat en els tres escuts del nivell inferior per indicar les arrels de la planta. Sorprèn, en tot cas, que mentre damunt el jacent I'heràldica familiar es repeteix de forma obsessiva, insistentment distribuïda damunt la indumentària i les armes que recobreixen el difunt -al casc, a l'espasa, al cinyell, als espe- 


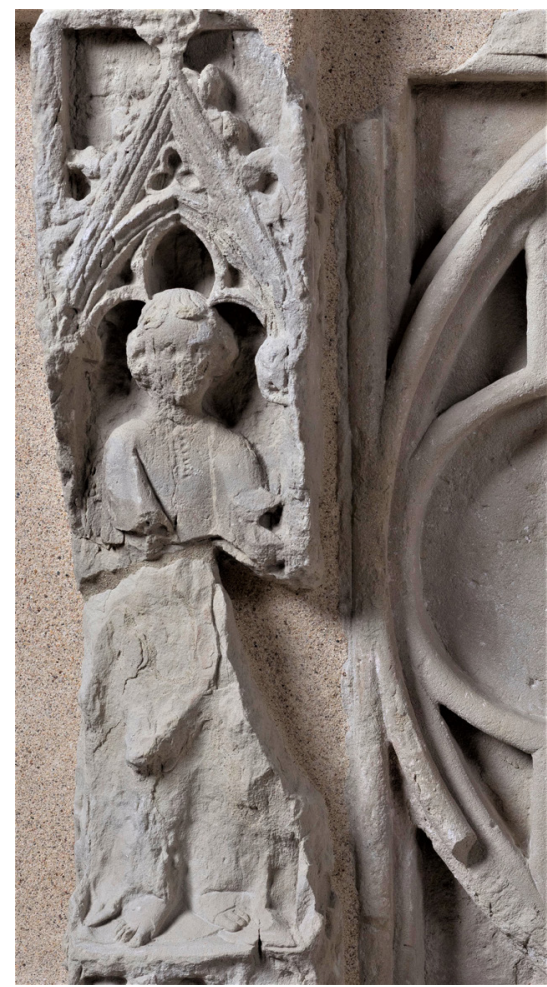

Fig. 15. Muntant amb figura d'àngel $o$ acòlit reintegrada al sepulcre en la restauració del 2019-20. (C) CRBMC Centre de Restauració de Béns Mobles de Catalunya. Fotografia de Ramon Maroto. rons, al perpunt que cobreix la cota (Fig. 20) -, en canvi, al sarcòfag, amb l'apostolat a l'enfront i el Crist entre àngels i tetramorf als peus, I'únic element heràldic visible sigui aquest gran escut de lectura problemàtica i ubicat en la cara menys visible si I'emplaçament original fos el que acaba de recuperar.

Tot plegat permet plantejar seriosament la hipòtesi que el túmul del Prohom Vinculador sigui un muntatge factici, recompost amb elements procedents de diverses tombes, cosa que explicaria la seva extrema singularitat tipològica, sense cap paral·lel conegut en I'escultura funerària catalana. ${ }^{43} \mathrm{Vist}$ amb aquesta suspicàcia, el conjunt té I'aparença de dos sarcòfags superposats, encara que separar els dos nivells no sigui tan simple com fora de desitjar. Jacent i sarcòfag podrien no anar aparionats si finalment la seva heràldica no coincidís, mentre que com a mínim el relleu central del registre baix

amb el cavaller Cardona al galop sí hauria de formar part del mateix sepulcre que el jacent. Per motius formals i iconogràfics que ja hem comentat, tampoc no és gaire clar que originalment el cavaller anés acompanyat dels dos compartiments amb monstres que, en flanquejar-lo, van generar la Ilegenda de la ceguesa del vescomte. Separar-los i cercar-los Ilocs alternatius en dos conjunts diferents no és senzill, encara que podem invocar exemples de cavallers solitaris en tombes catalanes contemporànies com són les dels comtes d'Urgell a Bellpuig de les Avellanes i dels Montcada a Lleida. A la primera sabem de I'existència del cavaller, ara perdut, per un gravat antic, mentre que una figura similar es conserva a la Seu Vella procedent dels desmantellats sepulcres montcadins. ${ }^{44}$ Aparentment les dues eren més exemptes que el nostre relleu i la conservada a Lleida deixa clar per l'estendard que arrossega que el seu significat s'ha de relacionar amb el ritual funerari del córrer les armes, un context difícil d'assignar al nostre 
${ }^{45}$ Vegeu pintura i segells a M. de Riquer, L'arnès..., figs. 30 i 53-55, a més de les figs. 67 i 99-100 amb detalls de la nostra tomba pobletana, encloent el relleu que comentem; la similitud amb motius sigil-logràfics ja ha estat anotada a F. EsPAÑol, El gòtic..., p. 125.
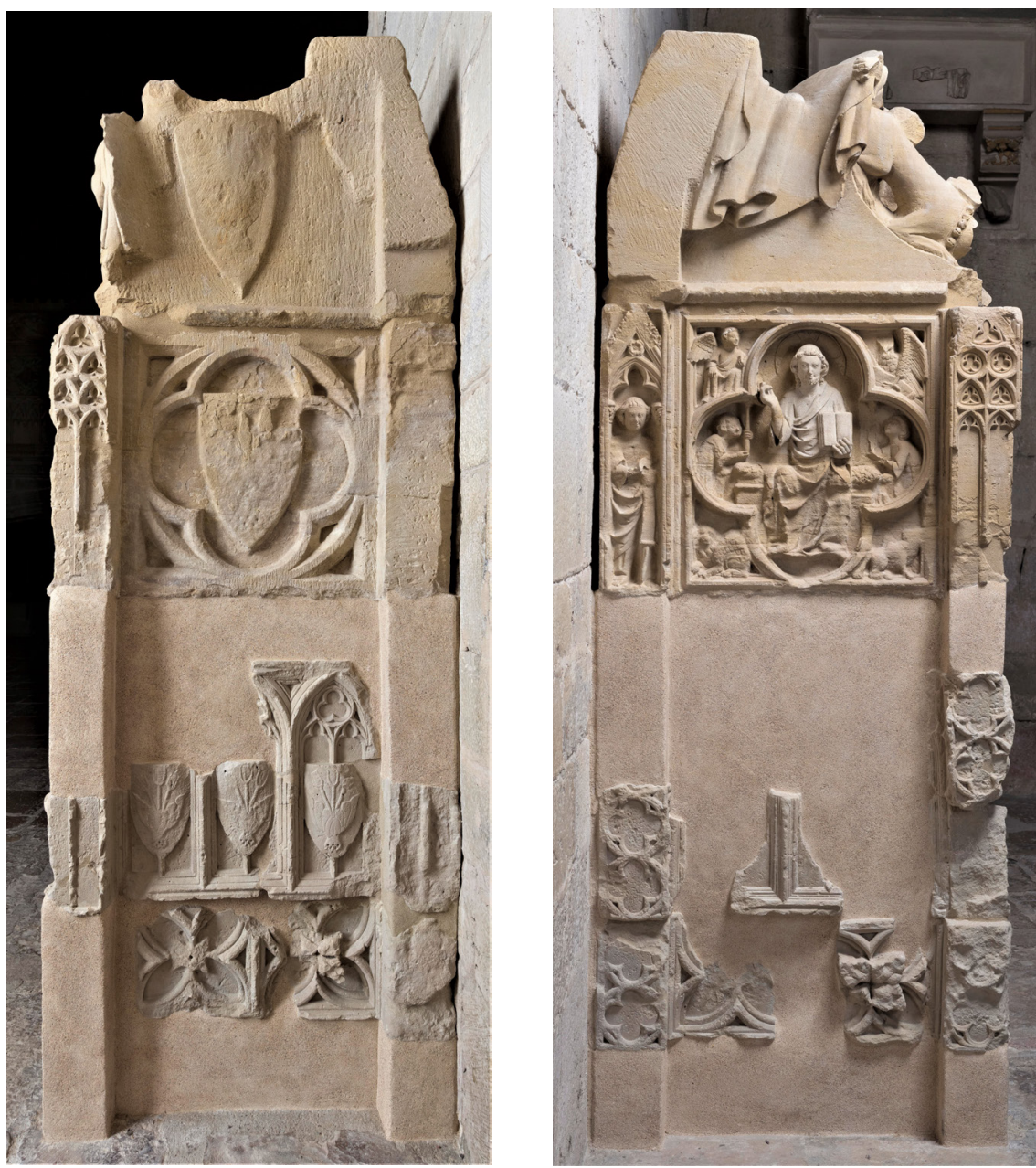

Fig. 16. i Fig. 17. Cares curtes a la capçalera i els peus del sepulcre amb els diferents elements reintegrats (C CRBMC. Fotografia de R. Maroto).

cavaller al galop brandant l'espassa dreçada, que esdevé així un exemple singular pel seu dinamisme. Aquest, i també l'emmarcament circular, recorden més aviat I'aspecte dels cavallers armats insistentment representats en segells, on és habitual veure espases alçades, encara que I'exemple en què la forma de brandar-la per darrera el cap que més s'assembla al relleu funerari és un ben conegut fragment de pintura mural de darreries del segle xiII conservat a la Biblioteca Balmesiana de Barcelona. ${ }^{45}$

En tot cas, les disparitats de disseny i els desajustos iconogràfics no han de fer oblidar el pes unificador de la dimensió estilística i molt especialment el paper que en això representen els muntants amb àngels que en 


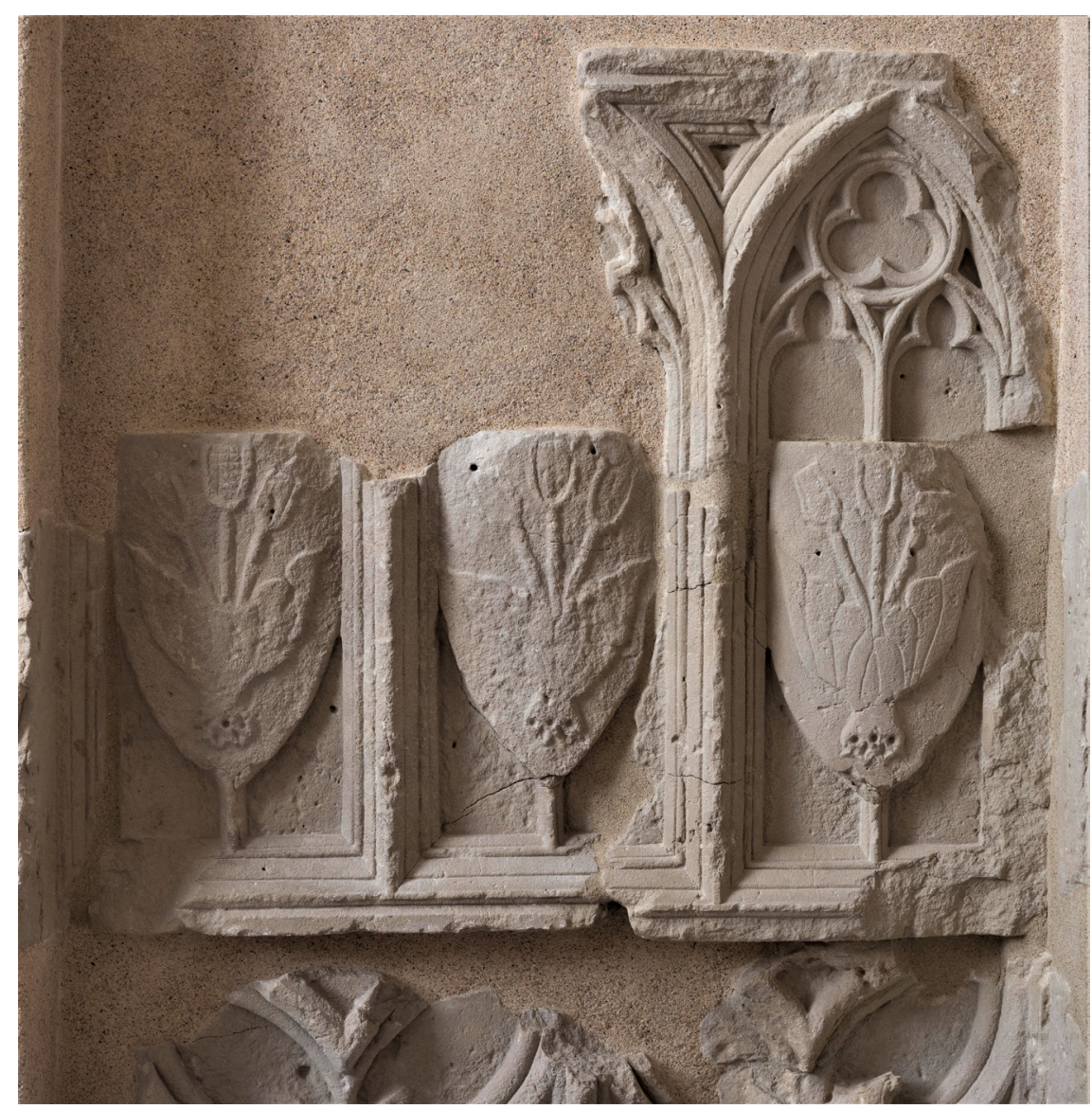

${ }^{46}$ A. Duran i Sanpere, Els retaules..., p. 26.

Fig. 18. Plafó amb escuts Cardona reconstruït en la restauració de 2019-20. (C) CRBMC Centre de Restauració de Béns Mobles de Catalunya. Fotografia de Ramon Maroto.

els dos nivells separen els tres plafons frontals. Malgrat la desigual conservació, haver pogut recuperar fragments més o menys grans dels quatre muntants solts que s'han ubicat al registre baix és un aspecte que l'agermana innegablement amb els que, al nivell superior, no s'han mogut mai de I'enfront del sarcòfag monolític, on separen els tres grups d'apòstols. La variable estilística que taxonòmicament s'agrupa sota el nom de Mestre d'Anglesola -l'autor del retaule procedent d'Anglesola i ara al Museu de Boston-s'adequa bé als trets formals de totes les parts figurades del sepulcre, com ja va assenyalar Duran i Sanpere en formular la primera aproximació a l'anònim escultor. ${ }^{46}$ Els esmentats muntants amb àngels, I'apostolat i el relleu centrat per la Maiestas aporten dades suficients per a admetre aquesta atribució d'acord amb els tipus de rostres, posats i plegats, i la seva minuciositat i el seu detallisme també s'adiuen amb la refi- 
47 Ja ens hem referit més amunt al cap del Museu Marès hipotèticament considerat part $d^{\prime}$ algun $d^{\prime}$ aquests àngels en base, precisament, a les dades estilístiques.

${ }^{48}$ Als monstres del sepulcre i als d'aquests capitells del retaule -que tant recorden els capitells reals del claustre de Santes Creus, si més no pel que fa a temàtica- Duran també agermana els de les mènsules de la porta del cor de la catedral de Tarragona (A. Duran i SANPERE, Els retaules..., p. 26), ara desmuntada i guardada als fons del museu catedralici, segons m'aclareix amablement Antoni Conejo.

49 Antigualles..., fol 19r ( $R$. del Arco, Sepulcros..., p. 484). L'abat Prada esmenta també el testament de 1296, sense referir-se a cap d'anterior, però no es limita a copiar les Antigualles perquè afegeix que en aquest testament també es deixaven al monestir "un cavallo y algunas mandas» (V. Prada, Sepulcros..., fol. 93, vid. R. del Arco, Sepulcros..., p. 625).

${ }^{50}$ Dóna notícia d'aquest nou testament, desconegut pels cronistes antics, J. Serra Vilaró, Història..., 1966, p. 231 i 265; $n$ 'hi fa referència F. EsPañoL, "El Mestre...», p. 89, que comenta el conflicte que va suposar el trencament de la tradició de la nissaga d'enterrar-se a la canònica de Sant Vicenç de Cardona, on sí van demanar ser enterrats els dos fills del Prohom en els respectius testaments de 1332 i 1334, esmentats a J. Ballaró i J. Serra y Vilaró, Historia de..., p. 88 i 92.

${ }^{51}$ La data precisa, coneguda per Finestres, figura al Necrologi de Solsona, publicat per Jaime Villanueva, Viage a las Iglesias de España, vol. IX. Via- nada execució dels elements que cobreixen el jacent, tot i que hi faltin per a certificar-ho el rostre repicat del difunt i els caps trencats dels àngels que I'envolten. ${ }^{47}$ Plantegen més dubtes, com ja dèiem, els dos relleus amb monstres, tant pel material com pel disseny de la traceria i l'escala de les figures. Ja hem comentat que en el corpus de I'anònim hi ha monstres $d^{\prime}$ aquest tipus al retaule $d^{\prime}$ Anglesola, a una escala molt menor i amb un sentit bàsicament ornamental, que és el que devien tenir també als dos plafons pobletans, segurament en un emplaçament més discret abans que la seva reubicació fomentés la invenció de la llegenda de la seva lluita amb el vescomte. El seu estat de conservació dificulta una comprovació més precisa de la seva variable estilística i el grau de versemblança de la seva adscripció al mateix taller del Mestre d'Anglesola. ${ }^{48}$

No som per ara capaços d'anar més enllà en la valoració dels diferents elements que en l'actualitat configuren la tomba, però creiem que hi ha prou arguments per insistir en el seu caràcter factici, organitzat a partir d'elements pertanyents en origen a més d'un sepulcre. Saber com era originalment la tomba de Ramon Folc de Cardona sembla un propòsit incert que només es pot abordar plantejant hipòtesis obertes, a falta de dades segures relatives al moment de creació de l'obra.

\section{Origen, antecedents i desplaçaments de la tomba}

El que sí podem donar per cert és que el 1296 el vescomte "confirma en son testament lo que en altre molt abans havia fet, ço és, que'l soterrasen en Poblet ${ }^{49}$, un desig reiterat en un nou testament del $1319 . .^{50}$ Sabem també que va morir el primer de novembre del $1320,{ }^{51}$ però no és tan clar precisar on va tenir lloc el decés; ja hem llegit a les Antigualles que «morí segons diuen les cartes el 1320 en parts molt Iluins, emperò no diuen a on», ${ }^{52}$ però Finestres assegura que va morir a Girona "y depositado su cuerpo en una de las Iglesias de aquella ciudad».53 Per contra, a les Antigualles s'hi anota que fou a la seu de Barcelona on fou dipositat un cop dutes les despulles des del lloc ignot de la defunció. ${ }^{54} \mathrm{Hi}$ ha consens en què el definitiu trasllat a Poblet va tenir lloc el 1322, però només Finestres anota que aleshores fou «sepultado conforme testamento en tierra Ilana donde estuvo hasta que fué puesto en sepulcro elevado de tierra». ${ }^{55}$ Aquest enterrament en terra, en un o diversos llocs, fa pensar en els processos en què els cossos són consumits abans d'un enterrament definitiu de les despulles en osseres més o menys grans. Però una tal consumició no s'adiu gens amb el cadàver intacte i gegantí que fou descobert i admirat pels qui el 1669 el traslladaren de la sepultura gòtica a la barroca. 


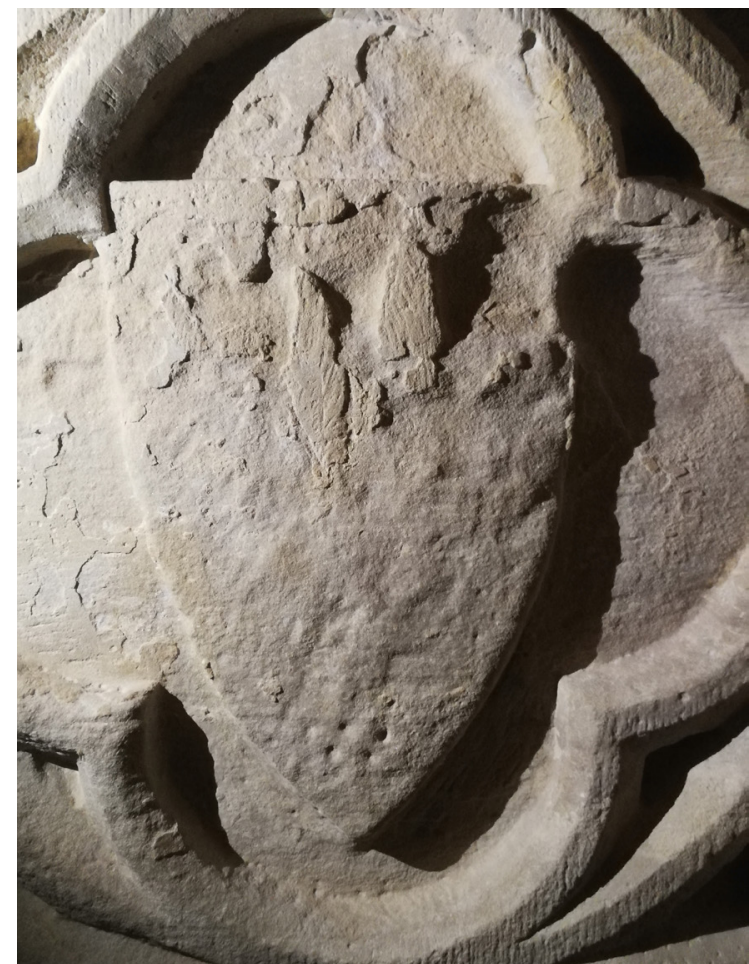

Fig. 19. Escut deteriorat a la capçalera del sarcòfag (C) CRBMC Centre de Restauració de Béns Mobles de Catalunya. Fotografia de Ramon Maroto.

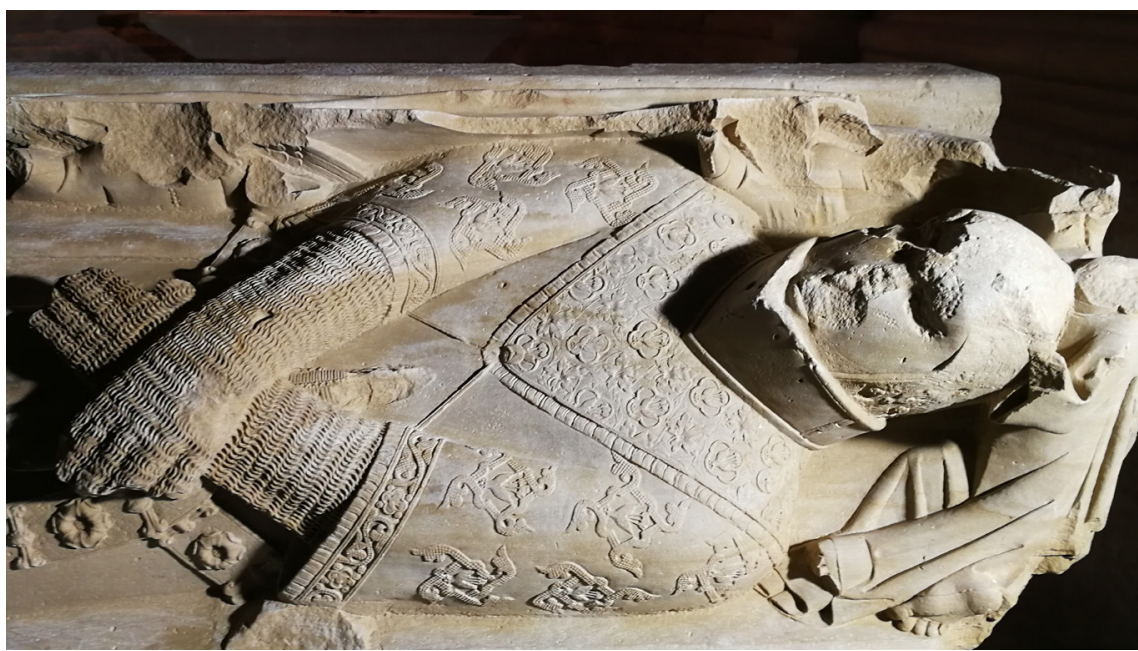

Fig. 20. Figura jacent amb escuts Cardona en diversos emplaçaments. (C) CRBMC Centre de Restauració de Béns Mobles de Catalunya. Fotografia de Ramon Maroto. ge a Solsona, Ager y Urgel, Valencia, 1821, p. 238. Deuen ser lapsus tant el 1322 que assenyalen com a data de la mort Duran i Sanpere i els seus seguidors (A. Duran i Sanpere, Els retaules..., p. 26, Núria de DALMASEs i Antoni José I PITARCH, I'art gòtic S. XIV-XV (Història de l'art català, III), Barcelona, 1984, p. 114) com el 1319, que apunta Español (Francesca EsPAÑoL, "La catedral de Lleida: arquitectura y escultura trecentistas», dins Congrés de la Seu Vella. Actes, Lleida, 1991, p. 181-213, nota 15, i F. EsPañol, El gòtic, p. 124).

${ }^{52}$ R. del Arco, Sepulcros..., p. 484.

53 J. Finestres, Història..., II, p. 160. Altisent, segurament Ilegint Finestres, dóna per bo l'enterrament provisional a Girona (A. Altisent, Història..., p. 247).

${ }^{54}$ Prada es limita a esmentar la ciutat de Barcelona com a Iloc del dipòsit, seguint parcialment allò llegit a les AntiguaIles; vegeu un i altre a R. del Arco, Sepulcros..., p. 484 i 625.

55 J. Finestres, Història..., II, p. 160. Reitera aquesta idea en un altre lloc quan escriu que entre 1322 i 1669 va estat una part del temps «sepultado en tierra llana y parte en un sepulcro de piedra ordinaria», el gòtic previ al siscentista, malgrat que en el mateix paràgraf ha dit abans que «fue puesto en el sepulcro antiguo en el [año] de 1322» (ídem. I, p. 301-302). Altisent es fa ressò de les dues versions: al·ludeix a l'enterrament a la tomba gòtica ja el 1322 en un lloc (A. Altisent, Història..., p. 526) i dóna per bo en un altre que aquell any fou sepultat a terra, ajornant la confecció del «magnífic sepulcre» fins a la segona meitat del segle $X I V$, en una sorprenent afirma- 
ció errònia sense cap tradició ni continuïtat (ídem, p. 246-247).

${ }^{56} \mathrm{El}$ fet que aquest darrer fos casat amb Beatriu d'Anglesola s'ha considerat especialment significatiu per la relació entre les escultures de la tomba i el retaule $d^{\prime}$ Anglesola (F. EsPAÑOL, «El Mestre...», p. 89). No és cert, però, que Hug fos I'hereu del Prohom Vinculador, sinó el germà petit que succeí I'hereu Ramon Folc quan aquest morí el 1332 sense descendència; d'altra banda és paradoxal que es consideri significatiu el matrimoni amb Beatriu $d^{\prime}$ Anglesola en relació amb el retaule quan en el mateix Iloc es dubta que aquest fos fet per a I'església d'Anglesola. Els vincles entre Cardona i Anglesola tenen altres dimensions que no pretenem ara explorar.

${ }^{57}$ Vegeu el que sobre tot això diuen les Antigualles i Prada a R. del Arco, Sepulcros..., p. 491, 493-494 i 624-625. Remarquem, però, que aquestes dades poden semblar parcialment contradictòries amb les que aporta Serra i Vilaró quan apunta que al testament del 1241 de I'avi del Prohom no s'hi esmenta lloc d'enterrament i que Maria Álvarez de Haro, la vídua morta el 1343, es feu sebollir a Solsona (J. Serra Vilaró, Història..., p. 197 i 281).

${ }^{58}$ R. del Arco, ídem.

59 J. Finestres, Història..., I, p. 304. El segueix al peu de la lletra L. Domènech i Montaner, Historia y arquitectura..., p. 125-126, on també s'esmenta la tomba del Prohom Vinculador -i publica un dibuix de l'escut representat com a brodat damunt el perpunt del jacentsense dir on es trobava i considerant-la erròniament d'alabastre. Ja abans, el 1848, Bofarull donava referència d'aquest se-
En tot cas, és clar que la tomba fou feta després de la mort del vescomte el 1320 i amb certesa també després del 1322, encarregada uns anys més tard per algun dels seus fills i successors, Ramon Folc VII (+1332) o Hug I (+1334).56 Malgrat que un i altre van demanar als seus testaments ser enterrats a Sant Vicenç de Cardona, com tants altres membres de la seva nissaga, el Prohom Vinculador no era el primer a elegir Poblet com a Iloc d'enterrament. Si ens refiem de la nòmina que tant les Antigualles com Prada i Finestres fan d'altres Cardona medievals que havien volgut tenir la tomba al monestir, hem de destacar I'avi, la dona i la germana del Prohom. Efectivament, el vescomte Ramon Folc IV, mort el 1241, ja ho havia establert el 1207, el 1317 ho feu Maria Álvarez de Haro, segona esposa del nostre vescomte, i ja abans la germana d'aquest, Sibil·la, casada amb Àlvar, vescomte d'Àger, i morta el 1295 (o 1300) i duta a Poblet el $1323 .{ }^{57} \mathrm{Els}$ autors antics coneixen la ubicació de la tomba d'aquesta darrera, que era damunt la porta de l'església que dóna al claustre, així com la d'un remot Berenguer de Cardona, amb testament del 1177, sebollit en un sarcòfag de la galilea. ${ }^{58}$ Encara que traslladat a un altre $\mid l o c$, deu ser el mateix «sepulcro grande de piedra encajado en la parte del cementerio, a las espaldas de la capilla de N. P. S. Bernardo» en el qual, segons Finestres, estaven enterrats tan Berenguer de Cardona com el vescomte Ramon Folch iv (que ell anomena viII), atès que ell ja no l'anota entre les tombes de la galilea. ${ }^{59}$

A partir d'aquestes informacions sobre el que se sabia i es veia als segles XVI, XVII i XVIII podem remarcar algunes qüestions. D'una banda I'esment de la germana del vescomte casada amb Àlvar d'Àger ens recorda que la tomba $d^{\prime}$ aquest darrer forma part del conjunt funerari que els comtes $d^{\prime}$ Urgell organitzaren a Bellpuig de les Avellanes no gaires anys abans als enterraments pobletans d'aquests Cardona; no seria estrany pensar que per a ells -igual que poc després per als Montcada a Lleida- hagués existit també un pla funerari que afectés a més d'un membre de la nissaga, encloent la commemoració retrospectiva de difunts enterrats allí des de feia temps. Per altra ban$\mathrm{da}$, constatem la variabilitat en I'emplaçament $\mathrm{d}^{\prime}$ 'algunes tombes, que obliga a interrogar-nos sobre les ubicacions originals, encloent també la de la tomba del Prohom Vinculador. Ben mirat, situar-la arran de I'escala que puja al dormidor, allunyat d'altars i capelles i sense gaire visió damunt el presbiteri, no sembla una elecció litúrgicament molt idònia, i més si pensem que en aquell moment encara no eren fetes ni decidides les tombes reials. Pensar en el seu trasllat a l'indret actual en algun moment posterior a la seva realització -abans o després de les altres manipulacions que ja hem esmentat i que reprendrem- no sembla descabellat. Atenent els usos de l'època i la presència de la tomba d'altres Cardona a la galilea, no seria inconcebible que aquest hagués estat també el destí primigeni de la del nostre vescomte. ${ }^{60}$ No és im- 
possible que allí, o a un altre 1 oc, ${ }^{61}$ haguessin estat fetes més d'una tomba dels Cardona, obrades pel taller del Mestre d'Anglesola.

Fossin on fossin, en algun moment entre la seva realització a l'entorn del 1325-1330 i la primera descripció del 1587 va tenir Iloc alguna mena de transformació de l'empresa, que enclou l'evidència d'una agressió intencionada, com ho palesa la damnatio memoriae en forma de repicat dels ulls del jacent. Ja hem plantejat la hipòtesi que això hagués tingut Iloc als primers anys de la guerra civil del segle XV, durant I'absència de I'abat Delgado des del 1462 fins al 1464, I'única època en què entre els segles XIV i XVI imaginem plausible una eventualitat d'aquesta mena dins del monestir. Si, a més de I'agressió al rostre del difunt, el sepulcre o sepulcres dels Cardona van ser malmesos de forma més àmplia i substancial hauria pogut tenir lloc immediatament després una recomposició amb elements de més d'una tomba i la reinstal·lació del muntatge resultant en el Iloc que coneixem. Aquesta eventualitat explicaria diverses qüestions, des d'un emplaçament protocol·làriament impropi fins una tipologia funerària insòlita, passant per un seguit d'incongruències formals i iconogràfiques a les que ja ens hem referit. ${ }^{62}$ Entre elles va tenir especial fortuna i conseqüències la poc congruent associació del relleu amb el noble Cardona a cavall i els altres dos amb éssers monstruosos, plantejada pels hipotètics reconstructors del túmul i exagerada pels ulls d'espectadors curiosos que van inventar la llegenda dels ratpenats, que reprendrem més endavant.

Pel que fa a la biografia de les pedres que I'havien generat, ja hem vist que túmul gòtic que el 1587 s'esmenta a les Antigualles seria substituït per una versió barroca del sepulcre, que evoca l'organització i la volumetria del gòtic. Aquest fou desmuntat el $1669^{63}$ i una part dels seus materials esculpits emprada com a material constructiu del basament massís del conjunt, mentre que el sarcòfag amb relleus i la seva coberta amb el jacent foren reutilitzats per a sebollir-hi el cavaller quatrecentista Rodrigo de Rebolledo, el cos del qual ja havia errat per diferents indrets dins una caixa de fusta. Finestres afirma que el sepulcre gòtic amb les despulles de Rebolledo «fue mudando con los tiempos diversos parages de la Iglesia» ${ }^{64}$, i encara que no ens diu quins, sabem per Prada, testimoni directe de I'operació setcentista, que en un primer moment la tomba havia estat situada «al cabo de la Iglesia, donde oy se mira a mano izquierda, como vamos del Coro a la Galilea, muy cerca de la capilla de S. Martín» ${ }^{65}$. Algunes dècades més tard, quan pels volts del 1700 el pare Fortuny es refereix a la tomba manllevant frases literals de Prada, hi incorpora entre parèntesi el comentari «que aun oy se ve en la capilla del Sto Sepulcro», una referència que deu remetre a l'altar que amb aquesta dedicació hi ha encara a la galilea on, doncs, el sepulcre havia estat traslladat. No hi va restar molt temps, car a mitjans del segle Xvin Finestres escriu que la tomba «hoy dia persevera puesta sobre el suelo, y arrimado a la pared, frontero a la pulcre amb els dos Cardona (dels quals dóna filiació precisa) al cementiri, i el comptabilitza setè dels nou que hi havia «en el paredón de la Iglesia, y espacio que media entre las espaldas de la capilla del Santo Cristo hasta detrás del Santo Sepulcro, por el lado de Occidente» (Andrés de Bofarull y Brocá, Poblet, su origen, fundación, bellezas, recuerdos históricos, curiosidades y destrucción, Tarragona, 1848, p. 68-69); Martinell ubica la tomba amb els dos Cardona al cementiri dels Ilecs, «al Iloc que hom foradà per engrandir la capella de Sant Bernat d'Alcira» (C. MartinelL, El monestir..., p. 234).

60 El primer esment escrit que tenim de la seva tomba, dins les Antigualles datades el 1587, ja la situa arran de l'escala del dormidor, però, com hem vist, aleshores el sepulcre ja havia estat manipulat i, potser, traslladat des d'una galilea, on la construcció feia molts pocs anys del conjunt del sant Sepulcre, encarregat el 1580 a l'escultor Andreu Ramírez, hauria pogut motivar alguns desplaçaments, sense descartar que algun fos anterior a aquest moment.

${ }^{61}$ La construcció a partir dels anys 40-50 de la tomba de Pere el Cerimoniós i del seu expansiu projecte de panteó dinàstic hauria pogut obligar a desplaçar en algun moment algun sepulcre prèviament ubicat prop de la capçalera del temple.

62 També així es podria explicar la incomprensible bona conservació d'un cadàver enterrat diversos cops a terra, atès que podríem pensar que, en realitat, la mòmia intacta descoberta en el trasllat siscentista no era el cos del Prohom Vinculador sinó el d'algun altre membre de la nissaga enterrat com ell a Poblet 
i amb la tomba fusionada a la seva. Recordem que allí havia estat enterrat el seu avi, els ossos del qual Finestres ubicava a la mateixa tomba on era un Berenguer de Cardona del segle XII. És curiós que a S. SobrequÉs, Els barons..., p. 112, s'afirmi que qui «fou un home de talla $\mathrm{i}$ corpulència extraordinàries» -les mateixes característiques físiques descrites per Prada- fou el pare del Prohom Vinculador (Sobrequés els anomena Ramon Folc IV i V), mort el 1276. 0 Sobrequés s'erra, assignant al pare el que els cronistes tardans deien del fill, o bé utilitza fonts diferents que podrien confirmar una confusió de cadàvers com la que suggerim, malgrat que també cal recordar que el vescomte mort el 1276 havia demanat en un testament de I'any anterior ser enterrat a Sant Vicenç de Cardona (J. Serra Vilaró, Història..., p. 228).

63 Recordem que al contracte per les obres del nou sepulcre els Grau es comprometien a «fer traurer la pedra de la sepultura vella y posar-la y retirar-la de lo puesto se li dirà» (C. MartinelL, «La casa de Cardona...», p. 93).

64 J. Finestres, Història..., V, p. 103; Altisent treu d'aquí la idea que la tomba fou traslladada diversos cops dins I'església (A. Altisent, Història..., p. 527).

${ }^{65}$ R. del Arco, Sepulcros..., p. 655.

66 J. Finestres, Història..., I, p. 324; la falta de concordança entre puesta (la tumba) i arrimado (el sepulcro) és a I'original; Finestres torna a esmentar aquesta ubicació al vol. V, p. 103.

67 Andreu de Bofarull, que no sap res de la reutilització de la tomba i creu que va ser feta capilla de N. P. S. Benito». ${ }^{66}$ Ja hem vist que Piferrer manté la referència a la proximitat a aquesta capella, oberta a llevant del transsepte meridional, i això permet plantejar si aleshores la tomba no seria a tocar de l'entrada de la capella, adossada al mur entre ella i la porta de la sagristia nova, centrada a I'extrem del transsepte. ${ }^{67} \mathrm{Si}$ fos aquest el mateix "rincón del crucero de la Iglesia» on la va veure Carderera no s'entendria la seva afirmació que «no descubre mas que el lado de los pies y su frontis». Aquesta observació potser permetria plantejar un posterior desplaçament del sepulcre des del costat esquerre de la porta de la sagristia nova, arran de la capella de sant Benet, fins al costat dret d'aquesta porta, arran de l'angle del transsepte i prop de la porta de I'escala de pujar al cimbori i el campanar que a inicis del segle xx prenen per referència, enlloc de la capella, tant els textos de Guitert, Martinell ¡ Toda, entre altres, com les fotografies més antigues ${ }^{68}$ (Fig. 21). Exposada des de 1835 a les violències i inclemències viscudes pel monestir devastat, al Ilarg del segle XIX la tomba podria haver estat no només desplaçada sinó també vandalitzada, com ho demostra el fragment recentment recuperat. ${ }^{69}$

Tan si hi va haver aquest desplaçament d'un racó a l'altre del mateix transsepte com si no, és clar que I'obra era aleshores formada exclusivament per sarcòfag i jacent, i no va ser fins que Toda va descobrir els elements fins aleshores ocults, emprats com a material constructiu al basament del túmul barroc, que va ser possible plantejar la reedificació del conjunt. Seguint sens dubte les descripcions parcials de les cròniques manuscrites de Prada i les Antigualles Toda va fer confegir l'estructura que mostrava, per sota de la caixa amb l'apostolat, els tres relleus amb el cavaller Cardona entre els dos monstres. Atès que, tot i que molt malmès, el

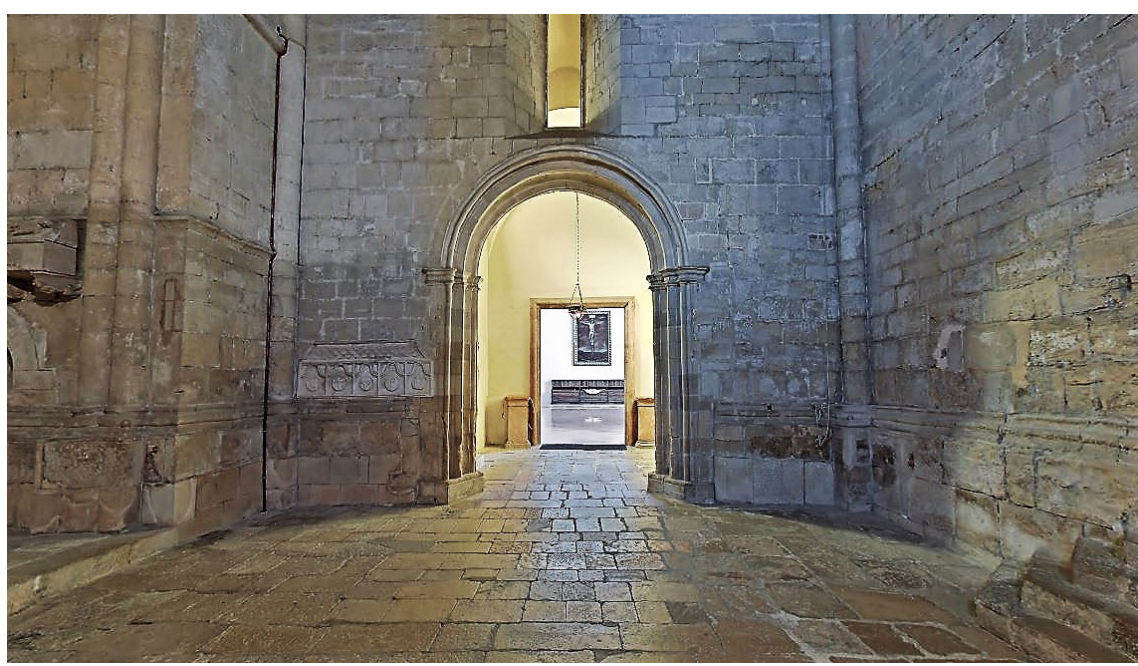

Fig. 21. Braç sud del transsepte on havia estat el sepulcre des del segle XVIII fins el 1933 
sepulcre barroc continuava al lloc arran l'escala del dormitori on havia estat el seu antecedent gòtic, ${ }^{70}$ la reedificació es va haver de fer en un emplaçament diferent, la citada capella de santa Úrsula de la nau lateral. Encara que és probable que la diligent actuació de Toda fos duta a terme de forma expeditiva, sense projectes previs ni memòries justificatives, ja hem vist que, gràcies a la seva correspondència amb Duran i Sanpere, en sabem la cronologia precisa l'estiu del 1933, i ens manca només una eventual documentació administrativa que detalli els dies exactes de I'operació $i$ els nom dels operaris que la van dur a terme. ${ }^{71}$

Aquella actuació va donar al conjunt funerari la forma amb què ha estat conegut i estudiat fins fa ben poc. El desembre del 2019, com ja ha estat dir, va començar l'operació de desmuntatge i desplaçament de tot el sepulcre fins al Iloc on havia estat fins el 1669, arran de l'escala que puja al dormitori, una mutació de Iloc que ha permès revisar a fons el monument: materialment amb la recuperació de diverses parts gòtiques; històricament, amb aquesta indagació sobre les seves vicissituds.

\section{El vescomte i els ratpenats. Formació i difusió de la llegenda}

El túmul ara refet reprèn el Iloc i la configuració que va perdre el 1669, quan va desaparèixer com a conjunt i van restar invisibles durant més de dos segles i mig algunes de les seves parts. Aleshores, però, ja s'havia format la llegenda que algunes de les parts amagades havien desvetllat en la imaginació dels observadors interessats en les pedres vetustes. La seva mirada curiosa i fantasiosa, precursora dels recursos propis dels guies turístics amb inventiva dels nostres temps -si no és que han existit des de sempre-, s'ha d'entendre i ubicar en un moment molt posterior a la seva creació gòtica i, en no llegir igual que els seus creadors elements que potser tampoc no havien estat fets per anar junts, va forjar la llegenda de la lluita del vescomte amb els diables i la subsegüent ceguesa, confirmada -però de fet motivadapels ulls arrencats de l'estàtua jacent. L'obra transformada genera, així, una relectura aliena a les intencions del creador però ja tan sòlidament adherida a les pedres com el sentit i els propòsits originals, si no més i tot.

No sabem quan fou inventada la història, i resseguir els camins pels quals es va difondre és encara més ardu i incert que perseguir les pedres que I'havien originat. Només sabem que ja existia el 1587 quan es narra completa a les Antigualles, i un segle després, quan el monument gòtic acabava de ser desmantellat, era recordada per Prada en el seu manuscrit, llegit i parafrasejat per diversos autors posteriors. És el cas d'un altre del monjos historiadors de per a Rodrigo de Rebolledo el 1479, la situa sense més precisions «en la [capilla] dedicada a S. Benito» en un text publicat el 1848 (A. de Bofarull, Poblet..., p. 46). El comentari lamentant que «sus huesos esparcidos en el polvo y su estàtua pisoteada vergonzosamente en el dia», ofereix una imatge de l'abandonament de mitjan segle XIX.

${ }^{68}$ De tota manera, tan en la ubicació hipotètica com en la certificada per les fotografies els peus de la tomba haurien de ser els menys visibles i no pas a I'inrevés, com afirma Carderera que, tal vegada, està simplement incorrent en un més dels errors i imprecisions que en aquest cas delaten el seu escrit.

69 Mai no va sortir, però, del monestir, en contra del que afirma Velasco (A. VelASCO, «Un nou fragment...», p. 214) en atribuir a la tomba gòtica les referències que fa Toda a les peripècies patides pel túmul barroc; és d'aquest que s'arrencaren escultures el 1854 per dur-les a Tarragona, que són «la urna del sepulcro del Prohom Vinculador en el crucero» que als anys 30 era retornada a Poblet; vegeu E. Toda, Panteones reales..., p. 27 i 36; altra cosa és que també retornessin alguns fragments gòtics menors, emprats en la reconstrucció de sepulcre trescentista el 1933 o romasos al dipòsit lapidari del monestir, on han estat retrobats i integrats a la nova presentació del conjunt medieval.

70 Resseguir les vicissituds del túmul barroc, amb els seus desmembrament i restauracions, ens desviaria massa del propòsit i les proporcions $d^{\prime}$ aquest estudi.

71 Amb aquests protagonistes materials de la intervenció $\mathrm{i}$ la documentació de la seva tas- 
ca cal vincular un episodi singular, del qual es dóna acurada explicació a A. GASet, Memòria d'intervenció..., p. 13, i que anotem també aquí per deixar-ne constància: durant els treballs de desmuntatge de la tomba per tal de desplaçar-la fins on és ara, els operaris van descobrir, i en aquell mateix moment trencar accidentalment, un recipient de vidre groguenc que contenia un líquid incert i el que sembla un rotlle de paper o pergamí amb anotacions fins ara il-legibles, atès l'estat endurit i corretjós que ha adquirit el material, dipositat al Centre de Restauració de Béns Mobles de Catalunya de Valldoreix per al seu estudi i eventual desxiframent. Sembla que la pràctica de deixar testimonis d'aquesta mena als fonaments 0 dins d'obres constructives no era estranya a començament de segle. En tenim un testimoni més solemne en la documentació colgada també dins tubs de vidre en col-locar la primera pedra de I'Hospital de Sant Pau el 1902, recuperats i ara exposats en la part musealitzada del conjunt modernista.

72 Aquest passatge dels manuscrits del pare Fortuny és publicat a J. Guitert, Col.lecció de manuscrits..., vol. 6, p. 133; de fet des de la p. 129 s'ocupa del Prohom Vinculador seguint el text de Prada al peu de la lletra; es refereix al personatge i a la tomba també en altres dels seus textos publicats per Guitert als vols. 4 (p.61) i 7 (p. 37).

73 V. CARDERERA, Iconografía... s.p.: «encontró acogida en el vulgo hasta fines del pasado siglo la conseja de que, jactandose el Vizconde de que seria capaz de pelear con los mismos demonios, "en castigo de tan vana jactància una bandada de la casa, fra Jaume Fortuny, que en un dels seus quaderns escrits pels vols del 1700 també parla del vescomte i de la seva tomba referint que «en la parte anterior estava esculpido a cavallo, armado de todas armas, peleando valerosament entre dos murcielagos», un dels molts fragments manllevats del Ilibre de Prada paraula per paraula. ${ }^{72}$ Finestres, que també usa extensament el text de fra Vicent sense confessar-ho, ja no es fa ressò en canvi de I'escena dels ratpenats, potser perquè també la trobava massa fabulosa i, a més, ja invisible. Tot i així, la llegenda va perdurar i, de fet, va esdevenir autònoma de la tomba real, essent recordada per autors que no podien o no sabien veure les escultures però tenien notícia de la narració bé per fonts escrites, bé per tradició oral. Carderera la recull atès que, com antic propietari del manuscrit de Vicenç Prada, llegat per ell a la Biblioteca d'Osca, hi havia llegit aquesta i altres de les dades que esmenta. ${ }^{73}$ Quan el 1904 Adolfo Alegret recorda la llegenda, cita un fragment de «un antiguo cronicón» anònim, que no és altre que el text de Prada, ${ }^{74}$ i Alegret és la font que molt després emprarà mossèn Serra i Vilaró quan recordi la història de l'aparició d'«un estol de grifons diabòlics demoníacs» que buida els ulls al vescomte. ${ }^{75} \mathrm{Ni}$ Alegret ni Serra i Vilaró no relacionen amb la tomba material el relat, que ells coneixen per via erudita, per bé que sembla que en paral·lel s'havia desenvolupar una versió popular transmesa oralment, de la qual només en coneixem testimonis tardans.

El 1945, en un Ilibre sobre Ilegendes de Poblet, Manuel de Montoliu n'ofereix una glossa lliure, molt literària i adornada, que enclou novetats com la de relacionar els fets del setge de Girona en què va participar el Cardona històric amb la faula de la lluita entre el cavaller i els ratpenats -visible amb una de les expressives il·lustracions de Julián Nadal (Fig. 22) -, o com el d'incorporar l'aparició del diable just abans de l'inici del combat. ${ }^{76}$ Aquest episodi diabòlic, absent del text dels cronistes, podria ser tingut per invenció de l'autor contemporani si no fos que, poc després, apareix també en la narració que publica Joan Amades, aparentment aliè tant a la redacció erudita com a l'òrbita cultural de Montoliu, ja que aclareix explícitament que la seva font és la tradició oral familiar. ${ }^{77}$ El seu relat a manera de rondalla, ampliat i enriquit respecte de les versions escrites dels cronistes, revela el seu to fantasiós en equívocs històrics, com el d'anomenar duc al vescomte, o en la incorporació elements sinistres, com l'esmentada aparició del diable enmig d'una tempesta de llamps i trons, just abans de I'atac dels ratpenats, o la referència a la tradició que aquests seguiren venint en «grans vols a visitar el sepulcre i a picar els ulls de l'estàtua jacent del brau cavaller, que ja els tenia menjats per indicar que era orb». Tot i esmentar la tomba, on "hi havia esculpida I'escena de la batalla amb les rata-pinyades», I'autor demostra no tenir gens present el conjunt escultòric real, del qual es parla com si fos al claustre i se l'evoca amb una il·lustració 


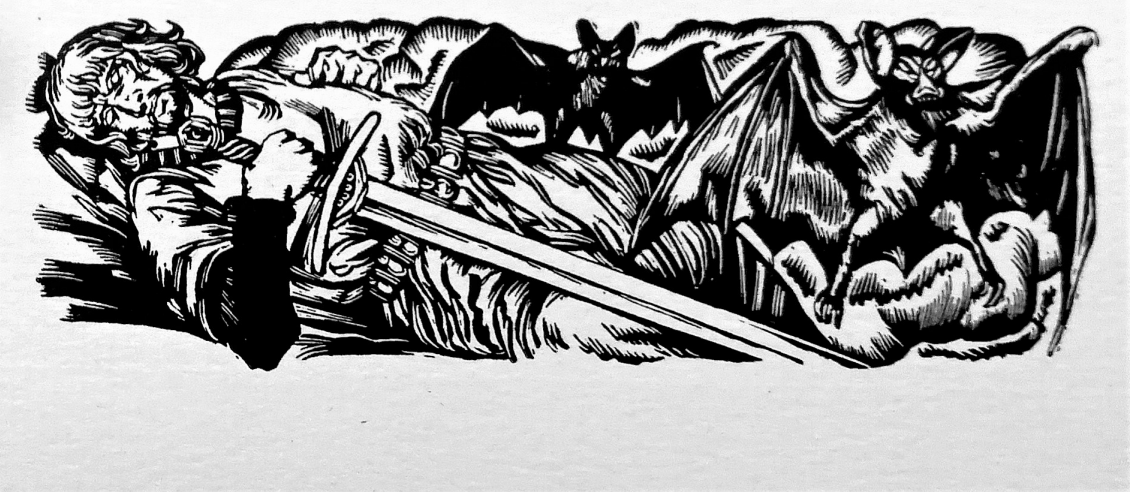

Fig. 22. Julián Nada: evocació de la lluita del vescomte amb els ratpenats, publicada a Manuel de Montoliu, Leyendas de Poblet, Barcelona, 1945.

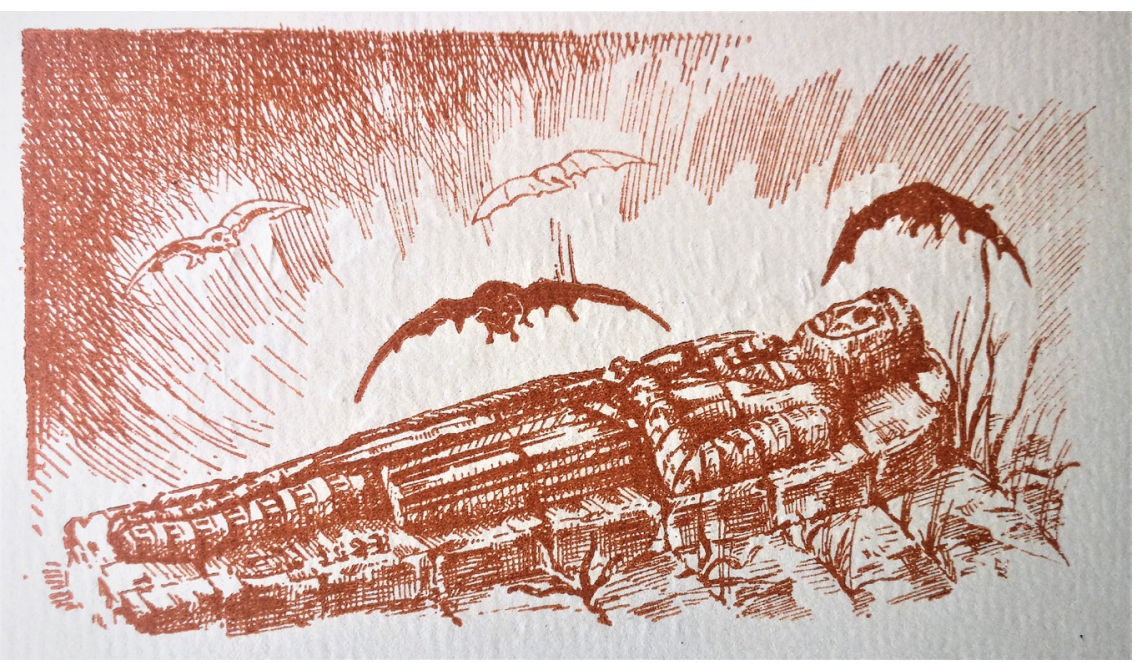

Fig. 23. Llucià Navarro: els ratpenats volant sobre la tomba del vescomte, il.lustració publicada a Joan Amades, Poblet. Tradicions i llegendes, Barcelona, 1947 espiritus malignos transformados en murcielagos le sacaron los ojos, por cuya razón se ve representado sin ellos en la estàtua que tenia en su sepulcro"»; més endavant, en comentar l'escultura remarca que «su estropeada cara y sin ojos (ya en este estado desde el siglo xviI), pudo tal vez dar pábulo a la conseja de que ya hicimos merito». Les referències al segle XVII han de remetre a Prada, però no he identificat a què es refereix quan parla de «fines del siglo pasado», és a dir, el xviII (potser a la tradició oral a la que em referiré més endavant, encara que va sobreviure molt més enllà d'aquell terme), ni qui està citant en el text que ell posa entre cometes, que no és pas el de I'abat siscentista. No deixa de sorprendre que, coneixent sens dubte el seu escrit, oblidi la qüestió del trasllat de la tomba i que, com hem remarcat, asseguri que "conserva su primitiva situación en la Iglesia».

74 Adolfo Alegret, El monasterio de Poblet, Barcelona, [1904], p. 78; el volum de 1904 recull una sèrie d'articles publicats prèviament a La Vanguardia; la part que ens interessa aparegué el 7 de gener de 1903, p. 4.

75 J. Serra Vilaró, Història..., p. 267, que remet a l'article periodístic del 1903 enlloc del llibre del 1904, cosa sorprenent en una publicació del 1966; és curiosa la manera com es designen els monstres, que sembla elaboració pròpia de mossèn Serra i Vilaró.

76 Manuel de Montoliu, Leyendas de Poblet, Barcelona, 1945, p. 109-124.

77 Joan Amades, Poblet. Tradicions i llegendes, BarceIona, 1947, p. 14-15; I'avi 
matern de Joan Amades havia estat escolà al monestir abans del 1835 i era fill i nét de sastres dels monjos i la mare del folklorista fou «un arxiu inexhaurible de tradicions» i llegendes llegades oralment al seu fill, dotat també d'una gran imaginació recreadora del folklore.

78 Ídem, p. 102-104; el gravat, obra d'un jove Llucià Navarro Rodon, sembla inspirar-se en el sepulcre gironí de Jofre Gilabert de Cruïlles, sense cap relació amb el del Prohom Vinculador.

79 Manuel de Montoliu, Poblet, símbolo. Visiones, leyendas, evocaciones, Tarragona, 1947, p. 125-128; Comparar aquest llibre, tenyit de ranci nacionalcatolicisme, amb el contemporani de Joan Amades de temàtica coincident, seria un exercici revelador que no ens correspon ara de fer. Montoliu, que es capaç de parlar de la recuperació de Poblet i de la restauració del sepulcre sense esmentar ni un sol cop Toda, expresa amb prosa carpetovetònica la convicció que la tomba «une a su merito artístico el interés de habernos conservado, plasmada en mármol [sic], una bella leyenda heroica de la Cataluña medieval, que parece arrancada de las páginas de una Canción de Gesta. También la Poesía puede vivir en la piedra y pueden también cantarla las manos de un escultor» (p. 128). El mateix text en versió catalana fou publicat deu anys més tard ( $M$. de Montoliu, Llibre..., op. cit., p. 114-119) i cal reconèixer que aleshores (a més de substituir el marbre erroni per un alabastre també equivocat) va afegir un paràgraf -que ja he que pren per model una sarcòfag distint del de Poblet ${ }^{78}$ (Fig. 23). Curiosament, el mateix any 1947, Manuel de Montoliu publica un altre volum de «visiones, leyendas y evocaciones» de Poblet, on recull una renovada presentació de "la leyenda de "el prohom Vinculador"», aquest cop despuIlant-la d'inventiva literària i tenint molt present tant el text de la crònica de Prada -tot i no citar-la de forma explícita i adequada- com també la tomba reconstruïda feia uns quinze anys. ${ }^{79}$

Posada per escrit a mitjan segle $x x$, la vella llegenda que havia estat relatada i enriquida al llarg de més de dos-cents anys sense fer-se visible per escrit ${ }^{80}$, acaba fusionant-se amb les lectures d'uns i altres, i quan la retrobem explicada en reculls recents, més que evocar la imaginació popular hi constatem la mera glossa del text d'Amades, enclosos els seus errors històrics. ${ }^{81}$ Nous guies potser recuperin i transformin la rondalla del vescomte altiu cegat pels ratpenats diabòlics, i potser I'ampliïn amb les desventures i les metamorfosis de les seves dues tombes, incorporant-hi els aclariments i les hipòtesis que hem mirat de plantejar en aquest treball, no aliè del tot a la fantasia o, si més no, a la imaginació imprescindible per a reconstruir històries a partir de bocins diversos. Ajuntar-ne i trobar-los sentit ha estat aquí una tasca paral lela a la dels restauradors de diferents moments. Tant de bo no hagi estat debades i hagi esvaït dubtes, incerteses i ratpenats, a poder ser sense deixar-hi la vista.

Pere Beseran Ramon Universitat de Barcelona beseran@ub.edu 
ELS ULLS DEL VESCOMTE.

MIRADES, MUTACIONS I TRASBALSOS DEL SEPULCRE GÒTIC DE RAMON FOLC DE CARDONA, EL PROHOM VINCULADOR, A POBLET

Aquest estudi es vincula a la recent restauració del sepulcre de Ramon Folc VI de Cardona i a la seva reubicació dins I'església del monestir de Poblet i es proposa de resseguir a partir de fonts antigues les vicissituds dels diversos elements del desmembrat conjunt gòtic. S'hi revisen els seus elements i s'hi plantegen hipòtesis sobre el caràcter factici de l'actual estructura i sobre la damnatio memoriae infligida al rostre i els ulls del jacent, aspectes ja documentats al segle XVI. Ja aleshores havia estat inventada la llegenda sobre la lluita del vescomte amb els ratpenats diabòlics que el van cegar, en un interessant cas de relectura de les representacions medievals després d'haver estat manipulades.

Paraules clau: art medieval, art gòtic, escultura gòtica, escultura funerària, Corona d'Aragó medieval, Catalunya medieval, Poblet, vescomtes de Cardona, conservació del patrimoni

THE VISCOUNT'S EYES. THE GAZES, MUTATIONS AND UPHEAVALS OF THE GOTHIC TOMB OF RAMON FOLCH DE CARDONA, THE PROHOM VINCULADOR, AT POBLET

This study is linked to the recent restoration of the tomb of Ramon Folc VI of Cardona and its relocation within the church of the monastery of Poblet, and aims to trace from ancient sources the vicissitudes of the various elements of the dismembered Gothic ensemble. Its elements are reviewed and hypotheses are made about the factual nature of the current structure and about the damnatio memoriae inflicted on the face and eyes of the recumbent, aspects already documented in the 16th century. By then, the legend of the viscount's struggle with the evil bats that blinded him had been invented, in an interesting case of rereading medieval representations after they had been manipulated.

Keywords: medieval art, gothic art, gothic sculpture, funerary sculpture, Crown of Aragon medieval, medieval Catalonia, Poblet, Viscounts of Cardona, heritage conservation citat més amunt- on reconeix el mèrit i la responsabilitat de Toda en la reconstrucció de I'obra: havien canviat I'idioma i els temps.

80 És simptomàtic que no se' $n$ faci cap esment en publicacions vuitcentistes que en principi semblaries idònies per a fer-se'n ressò. És el cas de Las ruínas de Poblet, de Víctor Balaguer (op. cit), que, tot i ser una obra plena de digressions, narracions i llegendes i esmentar les tombes del vescomte, no diu res de la història dels ratpenats, segurament perquè en aquest tocant la seva font és el pare Finestres. Tampoc no se'n diu res, malgrat el títol del Ilibre, a Jaume Ramon I Vidales, Poblet. Narracions i llegendes, Vendrell, 1928, cosa que pot suggerir tan el desconeixement de la història en aquesta època com els interessos ben diferents del seu autor, més interessat en deixat testimoni de tafaneries de monjos que de fantasies llegendàries de gust romàntic.

81 Domènec Ribes Mateu, Legendarium. Guia per les I/egendes de la ruta del Císter, Barcelona, 2005, p. 29, on, ara sí, s'enclouen fotografies de la tomba reconstruïda, a més de referències no gaire exactes $a$ les seves característiques. 
Aquest article ha estat publicat originalment a Matèria. Revista internacional d'Art (ISSN en línia: 2385-3387)

Este artículo ha sido publicado originalmente en Matèria. Revista internacional d'Art (ISSN en línea: 2385-3387)

This article was originally published in Matèria. Revista internacional d'Art (Online IS S N : 2385-3387)

\section{MATÈRIA}

Revista internacional d'Art

Els autors conserven els drets d'autoria i atorguen a la revista el dret de primera publicació de l'obra.

Els textos es difondran amb la llicència de Reconeixement-NoComercialSenseObraDerivada de Creative Commons, la qual permet compartir I'obra amb tercers, sempre que en reconeguin I'autoria, la publicació inicial en aquesta revista i les condicions de la llicència: https://creativecommons. org/licenses/by-nc-nd/4.0/deed.ca

Los autores conservan los derechos de autoría y otorgan a la revista el derecho de primera publicación de la obra.

Los textos se difundirán con la licencia de Atribución-NoComercial-SinDerivadas de Creative Commons que permite compartir la obra con terceros, siempre que éstos reconozcan su autoría, su publicación inicial en esta revista y las condiciones de la licencia: https://creativecommons.org/licenses/ by-nc-nd/4.0/deed.es

The authors retain copyright and grant the journal the right of first publication.

The texts will be published under a Creative Commons Attribution-NonCommercial-NoDerivatives License that allows others to share the work, provided they include an acknowledgement of the work's authorship, its initial publication in this journal and the terms of the license: https://creativecommons.org/licenses/by-nc-nd/4.0/deed.en

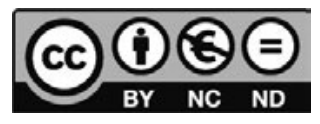

